\title{
THE GOLD CLAUSE IN PRIVATE CONTRACTS
}

\section{GEORGE NEBOLSINE $\dot{\dagger}$}

EVER since the Supreme Court in the Bronson case ${ }^{1}$ (1868) upheld the validity of a contract calling for the payment of a sum of dollars in gold coin, and gave judgment to the creditor in gold coin despite the fact that gold was at a heavy premium over legal tender, the gold clause ${ }^{2}$ has been virtually a standard feature of long-term private loans floated in the United States. ${ }^{3}$

Following the return of United States currency to the gold standard after the Civil War, and until the recent departure from that standard, this clause remained a dormant feature of the contracts containing it and aroused little interest among commentators. ${ }^{4} \mathrm{Ob}-$

iNember of the New York Bar; former editor of the Yale Law Joumal.

1. Bronson v. Rodes, 74 U. S. 229 (1868).

2. The usual form of gold clause embodied in domestic bond issues calls for the payment of "One Thousand Dollars $(\$ 1,000)$ in gold coin of the United States of America of or equal to the standard of weight and fineness existing on" the date of the loan. This must be distinguished from the gold coin clause discussed in the Bronson case which merely specified blank dollars "in gold coin." See The Effect of Revalorization of the Gold Dollar and the "zocight and fineness" Clause, infra p. 1075.

3. The "gold coin" clause is primarily an American development. The English practice prior to the War was to float foreign as well as domestic issues almost exclusively in Pounds Sterling, with no express reference to gold coin in the agreement. On the Continent, however, "gold" loans were fairly common, but these again did not usually specify gold coin of a standard of weight and fineness, but merely so many "francs or." This may be translated into American terms as so many gold dollars. In the United States, the preponderance of corporate mortgages are, however, payable in gold coin of a named standard of weight and fineness, and most Federal and municipal bonds contain a similar provision. It may be roughly estimated that about $95 \mathrm{~s}^{\circ} \mathrm{c}$ of all publicly offered securities in the United States, totalling upward of fifty billions of dollars in face value, contain the gold clause or some modification thereof.

4. Few studies have appeared treating the legal phases of this subject. The leading publications in English on this question are: HuNT, LAW of TENDErs (1903) ; BRECERNRIDGE, LEGAL TENDER (1903), a historical study of the legal tender concept; Madden and Nadler, Gold Clause (1929) INsTrTuTE of INTERnATIONAI FinaNCE, Bulletin No. 27 (Special Bulletin No. 4), a useful study of various types of clauses in international loans; Garis, The Gold Clarse (1933) 165 ANN. AMr. ACAD. 219, a very suggestive article laying special emphasis on state jurisdiction in the gold clause matter. MIadden and Nadler, The Gold Clause (1932) 12 BarroN's No. 23, p. 10 (June 6, 1932); and Adams, The Gold Clause (1932) 12 Barron's No. 34, p. 11 (Aug. 22, 1932), are briefer 
viously, so long as the currency in which the loan is contracted remained on a gold basis, that is, readily convertible into gold coin at par, and there existed no immediate fear of suspension of convertibility, holders of gold coin obligations have been willing to accept any form of currency at par in discharge of the obligation, and a creditor's invocation of the debtor's assumed duty to pay in gold coin would have constituted a mere formality. Consequently, until recently, the almost universal practice of debtors on obligations containing the gold clause has been to disregard the gold coin feature and to make the payments of interest and principal by setting up appropriate bank credits with their fiscal agents or making payment by check or in currency. In practical effect, a gold clause added nothing to the burden of the debtor.

However, the recent suspension of convertibility of currency notes and the imposition of a gold embargo, ${ }^{6}$ by threatening to create $\approx$ disparity between the value of the paper dollar and its statutory gold content, together with the power which may become vested in the President to reduce the gold content of the dollar, ${ }^{\circ}$ have now rendered extremely significant the gold clause provisions of private contracts. The problem of construing these provisions which now faces the large number of debtors and creditors immediately concerned with the performance of such contracts, warrants a detailed consideration of the legal effect of the gold clause. Such a discussion cannot be undertaken, however, without a prefatory reference to the rights of parties under debt contracts carrying ordinary currency clauses; nor would it be complete without some indication of the possible alternative measures of debt obligations, such as bullion or commodity clauses, available to future contracting parties.

\section{I \\ Currency Clauses}

Where an obligation merely specifies a certain number of "United States Dollars" or employs the symbol " $\$$ ", and repayment is to be made in the United States, there is no doubt that the creditor, suing in the country of payment, can obtain a judgment only for the sum stipulated in the contract, in legal tender. The medium of repay. ment of debts contracted in terms of currency is thus whatever the

discussions. Mention must also be made of the most comprehensive work on the subject in any language. NUSSBAUM, A., DAS GELD IN THEORID UND PRAxts DES DEUTSCHEN UND AUSLÄNDISCHEN RECHTS (1925).

5. The regulations which in effect put the United States off tho gold standard are analysed below. See note 84, infra.

6. See note 64 , infra. 
law has impressed with the character of legal tender. Legal tender may be defined as money which cannot lawfully be refused by a creditor. ${ }^{\top}$ In the United States the situation is somewhat complicated by the fact that there are a number of forms of money, having wide circulation, the legal tender qualities of which are doubtful. ${ }^{8}$

7. 1 BL. Conms. *276; HUNr, op. sit. supra note 4, at $61, \S 68$.

8. Under the Thomas Amendment to the Farm Relief Bill, Part VI, See. 34 (b) 1, it is provided: "Such notes and all other coins and currencies heretofore issued by or under the authority of the United States shall be legal tender for all debts public and private." This is a drastic extension of the Legal Tender Acts and is bound to raise constitutional questions in view of its uncertain legality. A brief summary of the tender characteristics of currency in circulation in the United States prior to the Farm Relief Bill is given below:

1. Gold coins-Legal tender in all payments at their nominal value. R. S. § 3585 (1878), 31 U. S. C. \$ 457 (1926).

2. Gold certificates-Legal tender in payment of all debts and dues, public and private. 41 STAT. 370 (1919), 31 U. S. C. $\S 451$ (1926).

3. Silver dollars-Legal tender at nominal value, for all debts and dues, public and private, except where otherwise expressly stipulated in the contract. 20 STAT. 25 (1878), 31 U. S. C. § 458 (1926).

4. Subsidiary silver coins-Legal tender for sums not exceeding $\$ 10$ in full payment of all dues, public and private. 21 STAT. 8 (1879), 31 U. S. C. § 459 (1926).

5. Minor coins-Legal tender, at their nominal value, for any amount not exceeding 25 cents in any one payment. R. S. $\$ 3587(1878), 31$ U. S. C. $\S 460$ (1926). It is lawful for the Treasurer to redeem in "Jawful money" under such rules as may be prescribed by the Secretary of the Treasury all copper, bronze, and copper-metal coins presented in sums of not less than \$20. 34 STAT. 132 (1906), 31 U. S. C. § 341 (1926).

6. United States notes-"Iawful money and a legal tender in payment of all debts, public and private, within the United States, except for duties on imports and interest on the public debt." R. S. $\S 3588$ (1878), 31 U. S. C. $\S 452$ (1926).

7. Silver certificates-Receivable for customs, taxes and all public dues. 24 STAT. 515(1887), 31 U. S. C. § 405 (1926).

8. Treasury notes-Legal tender in payment of all debts, public and private, except where otherwise expressly stipulated in the contract, and receivable for customs, taxes, and all public dues. 31 STAT. 47 (1900), 31 U. S. C. $\S 410$ (1926). Demand Treasury notes authorized by the Act of July 17, 1861, c. 5, and the Act of February 12, 1862, c. 20, are "lawiul money" and are legal tender in like manner as United States notes. Treasury notes issued under the Act of July 14, 1890, c. 708, are legal tender in payment of all debts, public and private, except where otherwise expressly stipulated in the contract. 26 STAT. 289 (1890), 31 U. S. C. $\$ 453$ (1926). Interest-bearing notes issued under Act of March 3, 1863, c. 73, and June 30,1864 , c. 172 , are legal tender to the same extent as United States notes for their face value, excluding interest, but not in payment or redemption of any notes issued by any bank, banking association, or banker, calculated and intended to circulate as money. R. S. $\S 3590$ (1878), 31 U. S. C. $\S$ 454 (1926). 
An examination of the statutes defining Federal Reserve Notes, National Bank Notes and Silver Certificates fails to reveal any provision that would make such notes legal tender for private debts. Such currency, if it is not legal tender, may be rejected by a private creditor of a "dollar" obligation. But the fact that the money which is tendered on the due date of an obligation stipulating payment simply in dollars, was made legal tender after the contract was entered into, and is of a different character, and is less valuable in terms of goods or gold than the legal tender in existence when the debt was contracted, is not a valid ground for a creditor's refusing it or for demanding a premium in excess of the stipulated amount of the debt.9 This was indubitably established, so far as American

9. Federal Reserve notes-Are obligations of the United States and shall be receivable by all national and member banks and Federal Reservo banlis and for all taxes, customs, and other public dues. They shall be redeomed in gold on demand at the Treasury Department of the United States, in the City of Washington, District of Columbia, or in gold or lawful monoy at any Federal Reserve bank. 38 STAT. 265 (1913), 12 U. S. C. $\$ 411$ (1926). In MacLeod v. Hoover, 159 La. 244, 105 So. 305 (1925), the Louisiana cour't indicated that Federal Reserve notes are good legal tender unless objected to by the recipient. But see under National Bank notes, infra.

10. National bank notes-The provisions governing the issue of these notes are contained in 12 U. S. C. $\$ 101$ (1926) et seq. No mention is hero made of legal tender quality. Section 109 (41 STAT. 387 (1920)) declares that "Any association receiving circulating notes under this chapter may ... issue, and circulate the same as money. . . And such notes shall be received at par in all parts of the United States in paymont of taxes, excises, public lands and all other dues to the United States except duties on imports; and also for all salaries and other debts and demands owing by the United States to individuals, corporations, and associations within the United States, except interest on the public debt, and in redemption of the national currency." 31 STAT. 46 (1900), 31 U. S. C. $\$ 455$ (1926). provides: "Legal-tender quality of money not affected by certain sections. Nothing contained in sections $146,313,314,320,406,408,411,429$, and 751 of this title, and sections 101 and 178 of Title 12 shall be construed to affect tho legal-tender quality as now provided by law of the silver dollar, or of any other money coined or issued by the United States. (Mar. 14, 1900, c. 41, \$ 3, 31 Stat. 46.)" Whether or not this section purports to bestow logal tender qualities upon national bank notes issued under Section 101 of Title 12 and Federal Reserve notes issued by the United States is not clear.

9. Legal Tender Cases, infra note 10. This was also the doctrine of the early English tender cases. In Poug v. DeLindsay, 1 Dyer $82 \mathrm{a}$ (1552), it was hold that an obligation to pay sterling might be discharged in legal tender, though the same was of baser alloy, the court declaring in the headnote, "If, at the time appointed for payment, a base money be current in lieu of sterling, tender at the time and place of that base money is good, and the creditor can recover no other." In the case of the Mixt Monies, Dav. Rep. 48 (1601), roparted in 1 Hate, Pleas to the Crown (1847) 192, the court held that an obligation to pay $£ 100$ sterling current and lawful money of England at Dublin, was dis- 
courts are concerned, by the decision of the Supreme Court in the Legal Tender Cases, ${ }^{10}$ holding constitutional the Act 11 which impressed United States notes with the character of legal tender for the discharge of debts. ${ }^{12}$

In so ruling, the Court recognized that the coinage power in the Constitution encompassed the right of Congress to make Federal notes legal tender; ${ }^{13}$ repudiated the contention that making the

charged by a payment in new coins declared legal tender in Ireland at their face value by proclamation of the Queen, although they were not sterling, but of a baser alloy, nor money current in England. As declared in 1 HuLE, op. cit. supra at 192, “ . . . the payment being to be made in Ireland, it was, as to that purpose, current money of England; . . ."

10. Knox v. Lee, Parker v. Davis, 79 U. S. 457 (1870) (hereinafter referred to as the Legal Tender Cases); and Juilliard v. Greenman, 110 U. S. 421 (1884).

11. Acts of February 25 and July 11, 1862, and Mrarch 3, 1863. 12 STst. 345, 532, 709 .

12. The constitutionality of the Legal Tender Act was vigorously debated in Congress in 1862 prior to its enactment. The bill was finally passed on February 25, 1862 and signed by President Lincoln on that day. The notes were issued and circulated freely, but gold and silver coin immediately rose to a premium over the notes. In Bronson v. Rodes, supra note 1, the Supreme Court held that the Legal Tender Act did not apply to contracts specifically calling for payment in gold coin and that such obligations were not subject to being discharged in legal tender at par. In Hepburn v. Griswold, 75 U. S. 603 (1869), the Supreme Court by a 5 to 3 majority held the Legal Tender Act unconstitutional as to pre-existing contracts and declared that contracts calling for payment in currency existing prior to the passage of the Act could not be discharged in legal tender at par even though they did not stipulate gold. After this decision the Attorney General made a motion to reconsider the constitutionality of the Legal Tender Act. The composition of the Supreme Court meanwhile was changed and the number of judges was increased to nine. In the Legal Tender Cases, supra note 10, the Supreme Court, by a 5 to 4 decision, upheld the constitutionality of the Legal Tender Acts in reference to debts prior to the Acts as well as following the Acts, thus reversing the decision in the Griswold case. One of the grounds most heavily relied upon by the Court was the imperative needs of the Government.

In Juilliard v. Greenman, 110 U. S. 421 (1884), the Court extended the judicially authorized powers of Congress to legislate in the matter of issuing legal tender notes by upholding the constitutionality of an Act of May 31, 1878 (20 STAT. 87), authorizing the reissuing of legal tender notes in peace time. See Anon., The Legal Tender Acts (1867) 2 Axr. I. REv. 403; Chamberlain, The "Legal Tender" Decision of 1884 (1884) 18 Asr. L. REv. 410; Talbot, The "Legal Tender" Decision of 1884; Reply to Gov. D. H. Chamberlain (1884) 18 AMr. L. Rev. 618; Smith, The Legal Tcnder Cases (1923) 9 A. B. A. J. 807.

13. Art. I, $\S 8$, of the Constitution provides that Congress shall have power to "coin money, regulate the value thereof. ..." It is clear that there is no express power to issue legal tender notes in the Constitution. The Supreme Court in the Legal Tender Cases, supra note 10, argued that the power to issue notes was a resulting power and was necessary and proper. 
notes legal tender constituted taking property without due process ${ }^{14}$ and declared that the prohibition against the impairment of obligations of contract had no application to the case.15 But while it held that legal tender notes were good tender for currency debts, the Supreme Court limited the decision to contracts which did not specify payment in gold coin. ${ }^{10}$ The American doctrine was thus established that, in the absence of contrary agreement between the parties, an obligation to pay money is to pay that which the law shall recognize as money when the payment is to be made.17 Fluctuations in the purchasing power, or the foreign exchange value, or the gold value of the currency will not affect the obligation, and the creditor of such an obligation assumes the risk of the depreciation of currency in terms of buying power or gold.18

While the question of the effect of a revalorization of the dollar was not raised in the Legal Tender Cases, as was that regarding the effect of a depreciation of legal tender, it also follows from the doctrine there formulated that a decrease of the weight and fineness of the gold content of dollars after the contract is entered into, and a consequent decrease in their purchasing power, will not affect the debtor's right to discharge his indebtedness by the pay-

14. Amendment $\mathrm{V}$ of the Constitution provides: "No person shall be . . . deprived of life, liberty or property without due process of law; nor shall private property be taken for public use without just compensation." Tho Court argued that this language was inapplicable in that it forbade talking private property for public use by direct appropriation but not consequential injuries resulting from the exercise of a lawful power. A learned decision of the New York Court of Appeals also dealt at length with this question. Metropolitan Bank v. Van Dyke, 27 N. Y. 400 (1863).

15. Art. I, §, 10, of the Constitution provides that "No State shall ... pass any ... Law impairing the Obligation of Contracts. ..." The Constitution contains no express prohibition against Congress passing such $\mathfrak{a}$ law, and the Court felt that Congress had power to impair the obligation of contracts. The Court declared: "If, then, the legal tender acts were justly chargeablo with impairing contract obligations, they would not, for that reason, be forbiddon, . . " Legal Tender Cases, supra note 10, at 550-1.

16. See Legal Tender Cases, supra note 10, at 548.

17. Legal Tender Cases, supra note 10. A number of state courts havo also passed upon the question of constitutionality of the Legal Tender Acts. These cases are not controlling and, for reasons of brevity, are therefore not cited. A learned decision of the New York Court of Appeals may be singled out for special attention, this case having been decided before the Legal Tender Cases. Metropolitan Bank v. Van Dyck, supra note 14.

18. In the Legal Tender Cases, supra note 10, the Court declared, at 548, that an obligation in terms of currency of a country takes the risk of currency fluctuations and, whether the creditor or debtor profits by the change, tho law takes no account of it. 
ment of the stipulated face amount of the new dollars, so long as the new coin or banknote is legal tender for "dollars." 10

It cannot therefore be seriously contended that it is not wholly within the power of the Federal Government to change the gold content of the unit of currency or to issue notes which are nonconvertible into gold, or to suspend convertibility of existing notes, or that creditors, in the absence of special protection by contract or of special limitation of the effect of such legislation on contracts entered into before the Act, have any contractual or constitutional basis for objection to payment in legal tender in satisfaction of their claims, regardless of the actual purchasing power of the unit tendered.

\section{II}

\section{Gold Clauses}

A solution of the legal problems bearing upon the enforceability of gold clause contracts depends not only upon the construction given the provisions of such contracts but also, to a considerable degree, upon the interpretation of the statutes defining and regulating money transactions generally. The utilization of a creature of statute-gold currency-as the measure or medium of the debt, introduces important elements of an ever changing statutory law as an intrinsic part of the contract. Any amendment of the statutes governing the issue and use of money may seriously affect the bargain which the parties have made. Thus, changes in the laws governing currency directed to the legal tender attributes of gold coin and other forms of currency, their legally defined value, the convertibility of one form of currency into other media of exchange, the possession of gold coin or its use by persons generally, its melting, earmarking or hoarding, may directly concern the rights of

19. See discussion of Act of 1834, by which the gold content of the dollar was reduced about $6 \%$, in the Legal Tender Cases, supra note 10 , and infro p. 1076. See Madden and Nadler, op. cit. supra note 4, at 25. There have been some exceptional instances where the State, following a catastrophic depreciation of its currency, has ceased to use the old unit of currency and has issued a wholly new and different monetary unit. In such cases revalorization of pre-existing debts on some basis is usual, and thus creditors are protected from a complete extinguishment of their claims. The most important case of this kind was the German Valorization legislation of 1925, growing out of the inflation of 1923. The Virginia Valorization Acts are also in point. See Scott v. Fornsby, 1 Call. 35 (Va. 1797). An examination of the operation of such legislation is beyond the scope of this article. 
parties to a gold coin contract.20 Of the most vital importance to the rights of parties under such contracts are the following three risks which will be examined in some detail: (A) The effect of depreciation of legal tender; (B) The effect of revalorization of the gold dollar and the "weight and fineness" clause; and (C) The effect of impossibility to procure gold coin.

\section{(A) The Effect of Depreciation of Legal Tender}

The suspension of convertibility of existing paper currency or the creation of non-convertible legal tender, if accompanied by a depreciation in the value of such currency in terms of gold, immediately raises the question of what performance may be required of a debtor under a gold clause contract. The significance of this for both debtor and creditor lies in the fact that if a gold coin clause, or its legal equivalent, ${ }^{21}$ is enforceable as an obligation to

20. It is to be noted that fluctuations in the purchasing value of gold or gold-based currency do not necessarily raise legal problems, but may involve purely economic risks, having only indirect legal repercussions in the inability of debtors to perform and the consequent insolvency or bankruptey of tho debtor, or, in the case of public debtors, in the default or ropudiation of tho debt. Fluctuations in the general price level of commodities are commonly regarded as fluctuations in the purchasing power of the currency, and, if such currency is on the gold standard, then the fluctuations represent changes in the value of gold. Warren and Pearson, Prices (1933) 66 et soq.; Laudimin, Money, Credit and Prices (1931) 447; Cassell, The Crisis in the World's MONETARY SYSTEM (1932) 40, 49. These fluctuations may be readily obsorved from any index of prices running over a long period of time. Thus, in tho last hundred years, wholesale commodity prices in the United States moved from 100 in 1821 to 88 in 1834 , to 129 in 1837 , to 73 in 1843 , to 115 in 1857 , to 83 in 1861, to 225 in 1864 (paper currency), to 86 in 1878, to 111 in 1882, to 66 in 1897 , to 100 in 1914, to 244 in 1920 (gold), to about 90 (gold) in January, 1933. WARREN AND PEARSON, op. cit. supra at 10. In other words gold in terms of commodity prices, almost doubled in value betweon 1882 and 1897; dropped over $50 \%$ between 1897 and 1914; between 1914 and 1020 droppod about $68 \%$, thus falling to about $25 \%$ of its value in 1897; between 1920 and 1933 róse about $157 \%$ in value. This last rise has meant that debtors today are obligated to pay principal and interest on outstanding loans in monoy having approximately one and one-half times the value in terms of commodities that it had in 1920 . In view of these fluctuations the inescapable conclusion is reached that gold or gold-supported money, both in times of peaco and in times of war, has proved unreliable as a standard of purchasing value.

21. The courts have held that an obligation to pay in gold coin will not be implied into a coutract which does not specifically call for it. Thus an obligation for the payment of a certain number of dollars, contracted at it time when the only legal tender money of the country was gold or silvor coin and the dollar was defined as a certain weight and fineness of gold or silver, will not be construed as equivalent in legal effect to a gold clause obligation if, prior to the due date, something other than coin is made legal tender. Legal Tender Cases, supra note 10. Thus in Woodruff v. Mississippi, 162 U. S. 291 
pay the nominal amount of the loan in gold coin, the risk of loss by reason of depreciation of the paper currency will be shifted from the creditor, who bears it under a currency clause, to the debtor.

With a view to clarifying the basis of the reasoning of the Supreme Court in rejecting, in the leading currency cases of the late sixties and early seventies, the adequacy of a tender of non-convertible depreciated notes in satisfaction of gold coin debts, it is important to note the general theories regarding the nature of money which have from time to time been current in the United

(1896), plaintiffs sought to enforce the lien of certain bonds, which the deiendant State of Mississippi contended were illegally issued. The defence was predicated upon the fact that the act under which these bonds had been issued by the levee board did not specify that the bonds were to be gold coin bonds. The bonds provided that the levee board "hereby acknowledge themselves, for value received, indebted to the bearer in the sum of one thousand dollars in gold coin of the United States of America, which said sum the said levee board ... do hereby bind themselves and engage well and truly to pay the bearer on the first day of January A.D. 1878." The coupons however provided merely for the payment of "twenty $(\$ 20)$ dollars in currency of the United States." The Supreme Court held that the bonds were valid obligations of the State and not being expressly payable in gold coin the obligation was to pay whatever was money of the United States. Similarly, the Supreme Court has refused to imply into a "dollar" contract from the surrounding circumstances of its inception, an obligation to pay in gold coin. In Mraryland $v$. Railroad Co., 89 U. S. 105 (1874), the State of Miryland made a claim for gold payments on certain stock issued by the railroad company to the State. The stock had been issued to the State in consideration for its issuing sterling bonds which were then sold by the company abroad. It was held, that this imposed no duty on the company to pay the State of Miaryland in gold coin after the Legal Tender Act was passed, though the State was compelled to discharge its own debt in sterling. A somewhat analogous situation developed in England in connection with the flotation of French franc Rentes in 1915, 1916, 1917 and 1918. Subscriptions were received at the Bank of England "with the consent and approval of His Majesty's Government," in pounds sterling at the then rate of exchange. After the franc dropped, the holders, paid only a small fraction of the interest on their loan, prevailed upon the British Government to try to obtain from France a settlement of these obligations upon more favorable terms. The French Government insisted, however, upon the right to discharge the bonds in the then current French francs. Correspondence respecting Position of British Holders of French Rentes issued in the United Kingdom in 1915-1918, France No. 1 (1931) cmd. 3779. See H. B. Samuer, The French DeFault (1930).

But in Trebilcock v. Wilson, 79 U. S. 687 (1871), the term "payable in specie" in a note was held to be descriptive of the kind of dollars in which the note was payable, and there being different kinds in circulation at the date of payment, to-wit: metallic and paper dollars, the term "in specie" was construed as calling for payment in gold or silver dollars of the coinage of the United States, this meaning having been acquired by the term among traders, merchants and bankers and in contradistinction to the term "in currency." 
States. The Constitutional Convention conceived of American currency as being essentially a commodity currency, composed solely of precious metals having, what was termed, intrinsic value. ${ }^{22}$ In the view of the framers of the Constitution, money was nothing more than so many pieces of precious metal of certified weight and fineness. The issuance of legal tender notes in $1862^{23}$ created an entirely new situation. Certain legal tender qualities were bestowed by Congress upon something having no "intrinsic" value in the sense that gold coin possessed such value. With the Federal Government treating the new currency as in many respects an altogether distinct currency, and discriminating against it, ${ }^{24}$ the Supreme Court had great difficulty in upholding its constitutionality. In more recent times, the idea of currency necessarily having "intrinsic" value has been abandoned. Money has come to be generally regarded primarily as a conventional medium of exchange, not necessarily consisting of a precious metal. Gold, whether in coin or bullion form, has now found its chief use in serving to secure paper currency and in acting as a restriction upon the volume of paper currency issued. As a result gold currency during the last few years has ceased to be issued in almost all countries. In the United States, the recent Executive Order ${ }^{25}$ restricting payments in gold coin by banks, followed shortly by Executive Orders ${ }^{26}$ requiring the return to the Federal Reserve Banks of coin and bullion in the hands of individuals, has resulted in a virtual withdrawal of gold coin from circulation. Indeed, we are now apparently on the threshold of an era of managed currency in which gold shall form a part of the security for currency, the volume of which may be subject however to legislative manipulation. ${ }^{27}$

22. This is fully discussed in Mr. Potter's argument against the constitutionality of the Legal Tender Act in the Legal Tender Cases, supra noto 10, at 465 . The country had returned after the horrors of an unredeomed papor currency to "absolute" money having an "intrinsic" value and neither had nor wished any other currency.

23. Notes 11 and 12, supra.

24. Legal tender notes were not receivable for customs duties, note 8 supra, and a judgment for coin was sustained in Cheang-Kee v. United States, 70 U. S. 320 (1865). The Act of March 17, 1862, 12 STAT. 370, authorized the purchase of coin with Treasury notes on the most advantageous terms. Tho Act of June 17, 1864, 13 STAT. 134, declared that thereafter loans of coin should not be made unless made payable in coin. The Act of March 10, 1866, 14 STAT. 5, required all returns on income to state whether made in legal tender currency or coin; and if in coin, then the assessor was to increase the assessment to the equivalent income in paper.

25. See note 80 , infra.

26. See note 82 , infra.

27. This question of managed currency is discussed by Pasvolsky, Tho Gold Standard Before and After the War (1933) 165 ANN. AM. ACAD. 171, 
The leading American authority on the effect of the issuance of non-convertible legal tender upon the rights of creditors under a gold coin obligation, is Bronson $v$. Rodes 28 (1868). The plaintiff, debtor under a bond secured by a mortgage for fourteen hundred dollars, payable "in gold and silver coin, lawful money of the United States with interest also in coin ...," tendered United States notes. ${ }^{29}$ At the time of the tender, coin dollars were worth considerably more than legal tender note dollars. Upon refusal of the tender, plaintiff deposited notes to defendant's account and sought equitable relief from the mortgage lien and a discharge of the debt.

The contention of the defendant was that, in the absence of a compelling reason of public policy, the Court was obliged to regard the four varieties of dollars then in circulation as equal in law, and to give the defendant the right to collect in gold coin. The plaintiff contended that the United States notes were legal tender; that Congress in prescribing the composition of coins had not made them uniform, but nevertheless had declared them to be of the same legal value; that it was recognized in the statutes ${ }^{30}$ limiting the amount for which copper and minor silver coins would be legal tender, that they were not intrinsically worth their nominal values but were made to bear a conventional value by force of legislation; and that Congress, having the power "to coin money, regulate the value thereof, and of foreign coin," 31 might debase coin, and the coin so debased would continue to be legal tender for the payment of all debts within the United States. At the time the contract was made there was no legal tender other than gold and silver, and even

173; Hardy, Gold and Credit, id. at 197; Nadler, The Partial Abandonment of the Gold Standard, 1931-1932, id. at 202. Casselt, THE Crisis in THE WORLD'S MTONETARY SYSTEM (1932) at 88: "To restore the Gold Standard is to bind one's curreney to gold, a commodity which, under present conditions and if no particular precautions are taken, must be regarded as singularly unsuitable for use as a standard of value."

28. 74 U. S. 229 (1868).

29. The first of the Legal Tender Acts, whereby the Secretary of the Treasury was authorized to issue United States notes, was passed on February 25, 1862 (12 StaT. 345). The Act provided that these notes "shall be receivable in payment of all taxes, internal duties, excises, debts and demands of all kinds due to the United States, except duties on imports, and of all claims and demands against the United States of every kind whatsoever, except interest on bonds and notes, which shall be paid in coin, and shall also be lawiul money and legal tender in payment of all debts, public or private, within the United States, except duties on imports and interest as aforesaid."

30. The amount to which silver, except silver dollars, could be tendered was limited to five dollars. 17 STAT. 427 (1872), 31 U. S. C. $\$ 316$ (1026). Copper coins were made legal tender for amounts not exceeding thirty cents.

9 STAT. 591 (1851).

31. Constitution, Art. $1, \S 8(5)$. 
without any stipulation calling for payment in gold, a money obligation was legally dischargeable only in coin. State banks had issued a quantity of notes, the convertibility of which into coin was uncertain, and these notes were not legal tender.

The Court faced the basic question squarely, eliminating procedural questions. Was the creditor required to accept United States notes equal in nominal amount to the sum due? Starting with the premise that it was obliged to enforce the contract in accordance with the true intent of the parties, the Court noted that when Congress authorized the issue of legal tender notes, it did not thereby affect the existing gold coinage. More specifically, the Court observed that: (1) Coinage of gold and silver coin was not suspended by the Legal Tender Acts; (2) The laws making gold coin legal tender were not repealed; (3) Customs dues were required by law to be paid in coin; and (4) There was no express enactment by Congress that contracts in a particular currency were not sanctioned by law. The Court, moreover, recognized that legal tender paper currency was not equivalent in value to metal currency. And it might be added that neither the possession of gold coin nor general transactions in coin at a premium over legal tender notes were prohibited or restrained.

The Court felt that for reasons of plain justice certain consequences had to follow from this:

(1) The enforcement of the obligation to pay customs dues in coin 82 required that merchants be enabled to buy coin and that the obligation of their vendees to deliver coin be enforced; similarly, that banks with which coin had been deposited for safekeeping be obliged to deliver coin to such depositors.

(2) The Federal Government itself might need coin and contract for it with banks; if it were held that notes were legal tender for all coin obligations, then the Government would be defeated in its object.

(3) The Government might desire to enter into obligations to deliver coin for bullion deposited with it; judicial sanction could not be given for the discharge of these obligations in notes.

Following this analysis of the reasons for its decision the Court declared:

32. In Cheang-Kee v. United States, supra note 24, cited by tho Court, judgment was entered in favor of the United States in coin for import duties. It had been held, moreover, by the Supreme Court in Lane County v. Oregon, 74 U. S. 71 (1868), that the Legal Tender Acts had no effect on the power of a state to collect taxes in gold coin. 
"A contract to pay a certain number of dollars in gold or silver coins is, therefore, in legal import, nothing else than an agreement to deliver a certain weight of standard gold, to be ascertained by a count of coins, each of which is certified to contain a definite proportion of that weight. It is not distinguishable, as we think, in principle, from a contract to deliver an equal weight of bullion of equal fineness. It is distinguishable, in circumstance, only by the fact that the sufficiency of the amount to be tendered in payment must be ascertained, in the case of bullion, by assay and the scales, while in the case of coin it may be ascertained by count." 33

The Court therefore concluded that contracts expressly stipulating payment in coin were not "debts" which might be satisfied by the tender of United States notes, within the meaning of the Legal Tender Act, and gave a judgment in gold coin for the amount of the obligation.

The Bronson decision has been criticized on the ground that it confused a money debt with an obligation to deliver specific articles. It is pointed out that from the remedial point of view, an obligation can be either a debt or a contract to deliver goods, but it cannot be both. ${ }^{34} \mathrm{~A}$ debt is dischargeable in the amount set forth and breach of a money obligation does not change the obligation -it remains a debt, which the law will enforce by ordering payment. The creditor of a money obligation gets a judgment in the amount of the debt. But if the obligation in the Bronson case was properly construed as a commodity obligation, then, it is contended, judgment should have been given in legal tender for damages, as the breach of the commodity contract creates a primary right only to collect money damages to the value of the goods contracted for. Following through this line of thought it may be argued that specific performance should

33. 74 U. S. 229, 250 (1868). (Italics supplied).

34. HUNT, op. sit. supra note 4, at 111. This work criticizes the Bronson decision on the following grounds: "In ordering a judgment to be entered for coined dollars, the Supreme Court of the United States clearly transcended its power and usurped that of the law-making power." (p. 111).

"The law of the land should be uniformly applied. No good reason can be advanced why, when a person desires gold or silver coin as bullion, to use in the arts, or for export, the purpose matters not, the vendee in such a contract is entitled to a judgment payable in that commodity only, while the law denies the right to have such a judgment to a vendee in a contract for pigs of lead, or of iron, or for any other commodity.

"Other points are suggested to us, wherein the decision in Bronson $\nabla$. Rodes does not harmonize with other branches of the law. It is in conflict with the legal definition of a debt, and of obligations to deliver specific articles. A contract providing for the payment of a certain number of dollars in gold or silver coin, is either a contract creating a debt, or an obligation for the delivery of that number of coined dollars as a commodity. The contract cannot be both." (pp. 112-13). 
never be granted to enforce contracts for the delivery of fungible goods and that therefore the judgment in gold coin was improper.

This apparent inconsistency in the decision arises from the reading of the case as one holding that a gold coin debt is a commodity obligation dischargeable in gold coin. A closer analysis of the case and of subsequent decisions of the Court indicates, however, that the judgment was not one of specific performance of a commodity obligation, but a judgment for the payment of a debt in a specific form of currency. In deciding the Bronson case Chief Justice Chaso was confronted with the difficult problem of determining what form the judgment should take. The difficulty arose from the supposition that damages could be assessed only in one description of money. The Act of 1792 provided "that the money of account of the United States shall be expressed in dollars . . . , dismes . . . , cents ..., and milles ........ and that all accounts in the public offices and all proceedings in the courts of the United States shall be kept and had in conformity to these regulations." ${ }^{35}$ The Court for the purpose of the decision assumed the constitutionality of the Legal Tender Acts and concluded that both gold dollars and legal tender dollars fell within the scope of the Act of 1792. Said Chief Justice Chase:

“. . . it is a just if not a necessary inference, from the fact that both descriptions of money were issued by the same government, that contracts to pay in either were equally sanctioned by law. . . Doubt concerning it can only spring from that confusion of ideas which always attends the introduction of varying and uncertain measures of value into circulation as money"; ${ }^{36}$

and added:

"When, therefore, two descriptions of money are sanctioned by law, both expressed in dollars and both made current in payments, it is necessary, in order to avoid ambiguity and prevent a failure of justice, to regartl this regulation as applicable alike to both." ${ }^{37}$

These extracts from the decision clearly indicate that the chief ground for the decision was that the Federal Government itself had impressed two different kinds of dollars with different legal tender qualities. In view of the fact that the Federal Government required that customs duties be payable only in gold coin; that it issued notes, some of which bore interest payable in coin and others in legal tender

35. 1 STAT. 250 (1792), 31 U. S. C. \& 371 (1926).

36. Bronson v. Rodes, supra note 1 , at 252 .

37. Id. at 254 . 
notes; and that notes bearing increased interest were substituted for notes bearing interest in coin, ${ }^{38}$ the conclusion of Chief Justice Chase is sound.

That the principal basis for the Bronson decision was the dual monetary system created by Congress, with gold coin having unigue characteristics as a currency, rather than the language of the Court interpreting the debt as a commodity obligation, is further confirmed by the reference to the Bronson case made by the Court in the Griswold case. Referring to the judgment it had entered to pay gold coin, it declared:

"This conclusion rested, however, mainly on the terms of the act, which not only allow, but require payments in coin by or to the government, and may be fairly considered, independently of considerations belonging to the law of contracts for the delivery of specified articles as sanctioning special private contracts for like payments; without which, indeed, the provisions relating to government payments could hardly have practical effect." 39

The italicized words clearly indicate that the analogy of the gold coin clause to a commodity contract should be deemed obiter.

Any argument against giving full weight to the language of the Court in the Griswold case, based on the fact that this case, denying the constitutionality of the Legal Tender Acts, was reversed in the Legal Tender Cases following a reconstitution of the Court, can be met by citing the very pertinent language adopted by the newly reconstituted court in Trebilcock $v$. Wilson ${ }^{10}$ a year later. Seizing upon an opportunity to re-argue the grounds for the Bronson case, the Court affirmed its decision and expanded the arguments in favor of the dual currency theory, ignoring the dangerous analogy of gold coin contracts to gold bullion or commodity obligations. This case is of great importance in the interpretation of the Supreme Court doctrine with respect to gold coin clauses. The Court declared:

"But here the terms, in specie, are merely descriptive of the lind of dollars in which the note is payable, there being different kinds in cireulation, recognized by law. ${ }^{41}$

38. Discussed in Legal Tender Cases, supra note 10, at 578. The practice and legislation of the Federal government inconsistent with the view that gold coin was treated on a parity with legal tender notes was discussed in detail by the Supreme Court in Trebilcock v. Wilson, supra note 21, at 695-697.

39. Hepburn v. Griswold, supra note 12, at 609. (Italics supplied).

40. Note 21 , supra.

41. Id. at 695 . 
"As the act of 1862 declares that the notes of the United States shall also be lawful money and a legal tender in payment of clebts, and this act has been sustained, by the recent decision of this court, as valid and constitutional, we have, according to that decision, two kinds of money, essentially different in their nature, but equally lawful. It follows, from that decision, that contracts payable in either, or for the possession of either, must be equally lawful, and, if lawful, must be equally capable of enforcement." 42

And, referring to the Act of $1792,{ }^{43}$ the Court added:

"The section has reference to coins prescribed by the act, and when, by the creation of a paper currency, another kind of money, expressed by similar designations, was sanctioned by law and made a tender in payment of debts, it was necessary, as stated in Bronson $v$. Rodes, to avoid ambiguity and prevent a failure of justice, to allow judgments to be entered for the payment of coined dollars, when that kind of money was specifically designated in the contracts upon which suits were brought." 41

It is more than likely that the cause for the analogy drawn by the Court in the Bronson case between a gold coin contract and a bullion obligation was the identity in result of construing a gold coin contract either as a debt or as a bullion obligation that obtained under the particular circumstances prevailing at the time of the decision. Assuming that an obligation to deliver coin were construed as a commodity contract and gave rise, on breach, to a judgment for damages, under the Court's dual monetary system a judgment might have been rendered either in currency or in gold coin. Since either form of judgment would be equally available, the parties might stipulate the one in which they desired to recover, and, failing a stipulation to the contrary, the Court could infer an intention of the payee of a gold coin obligation to receive his judgment in gold coin, because such a judgment would avoid the necessity of computing the value of the gold in terms of currency, equivalent in value to the commodity stipulated to be delivered, and also avoid the risk of depreciation in the value of legal tender before the judgment could be enforced. From the remedial point of view, therefore, the judgment granted for breach of contract would have been the same

42. Id. at 695-696. In Thompson v. Butler, 95 U. S. 694 (1877), the Court referred to a debt of $\$ 5000$ in gold and, after quoting the Bronson case in its reference to commodity obligations, added, at 697: “ . . . but, notwithstanding this, it is a contract to pay money, and none the less so because it designates for payment one of two kinds of money which the law has made a legal tender in discharge of money obligations."

43. Note 35 , supra.

44. 79 U. S. $687,698-699$ (1871). 
under the circumstances prevailing at the time of the Bronson case, whether the obligation was incurred as a gold debt enforceable under the dual currency theory or as a commodity obligation dischargeable in either of two currencies under the commodity theory; and for this reason the legal distinction between a gold coin debt and a commodity obligation to deliver a quantity of bullion was easily confused.

A bullion contract was in fact before the Supreme Court in the case of Butler $v$. Horwitz ${ }^{45}$ (1868), where the obligation due was on account of rent in the amount of $£ 15$, payable in English golden guineas, weighing five pennyweights and six grains, at thirty-five shillings each, and other gold and silver at their present (1791) established weight and rate according to the act of assembly. A judgment for damages assessed in currency notes to the bullion value of the gold was reversed by the Supreme Court. The Court interpreted the understanding of the parties to be "that such contracts should be satisfied whether before or after judgment only by tender in coin." 46 The Act of 1792 and the provisions of the contract requiring that satisfaction be made in gold, the Court declared, "require that damages upon such contracts be assessed in coin and judgment rendered accordingly." 47 This decision is consistent with the proper measure of damages for the breach of a contract to deliver a commodity; that is, the market value of the commodity. Where there is a dual system of currency-gold and notes-judgment might be rendered in gold. Where there is a single system of currency-notes-judgment for damages must, of course, be rendered in such currency.

In Gregory v. Morris 48 (1878), however, the Supreme Court by dictum swung back to the commodity theory. The Court itself distinguished the facts from the Bronson case as not involving a suit "upon the contract for the recovery of the amount agreed to be paid, but in effect for damages on account of the wrongful detention of property mortgaged to secure the debt." It also appeared that the party charged with the payment had asked the Court to compute the damages in legal tender. The Supreme Court, in this case, relying upon these facts and upon the Bronson dictum to the effect that a contract to deliver gold coin was not distinguishable from a contract to deliver bullion, felt that it was not compelled to give judgment in gold coin, and sustained the instructions given the jury below by the Wyoming Territory trial court to find damages by

\footnotetext{
45. 74 U. S. 258 (1869).

46. Id. at 261.

47. Ibid.

48. 96 U. S. 619 (1878).
} 
computing the difference between gold and currency and to render their verdict in currency.

In United States v. Erie Railway Co.40 (1882), the Court held that, as there was no difference in value between gold and currency, a general judgment for the amount due was sufficient, but declared that it would have been proper to render a judgment for coin or its equivalent in currency, if there were a difference in value. In this case, however, the sum owing was a tax upon a foreign gold coin debt, which might well have been viewed as a charge upon a commodity obligation.

These two cases, while they give currency to the commodity theory, do not add anything to the dictum in the Bronson case. The Morris case relied exclusively upon this dictum, and the Erie case cited only the Morris case in support of the dictum there expressed. But despite this rationale of these decisions bearing upon gold coin contracts, the fact must be recognized that the Supreme Court has taken an ambiguous position with reference to the, no cloubt, ambiguous gold coin obligation. In any event, it is to be noted that if a legal distinction between a gold coin debt and an obligation to deliver bullion is proper, the damages recovered for breach of a contract to deliver bullion may be very different from those recovered for failure to pay gold coin, where illegality or legal impossibility of paying out gold coin qua money is pleaded by a debtor under a gold coin contract. .0

The holding in the Bronson case was to the effect that, where there is governmental discrimination in favor of gold coin, a gold coin contract is enforceable as a debt in terms of that type of money. There is, however, no doctrine of specific performance applicable. to money contracts except insofar as the same result is reached within the narrow scope of this dual currency theory developed in 1868. Thus, in an early case decided in 1843, the question arose as to the judgment to be rendered in respect of a promise to deliver a sum of money in dimes. There was no difference between the value of silver and gold coin at the time nor was convertibility of the one into the other impaired, and the court declared the debt dischargeable in gold coin, silver dollars or dimes.51 This was sound law in the United States prior to the Legal Tender Acts and should not be deemed inconsistent with the Bronson case. It follows therefore that where gold coin is withdrawn from circulation and only paper currency remains (subsidiary coins aside), the Bronson case ceases

49. 106 U. S. 327 (1882), rehearing denied, 107 U. S. 1 (1882).

50. See The Effect of Impossibility to Procure Gold Coin, infra p. 1079, and Gold Bullion Clauses, infra p. 1088.

51. Atchafalaya Rr. \& Banking Co. v. Bean, 3 Rob. 414 (La. 1843). 
to be directly applicable and, unless the obligation is construed as a commodity contract (a construction which the Supreme Court did not clearly adopt), great difficulty may be experienced in giving the words "gold coin" any effect. 52

The Bronson case may be profitably compared with the recent (1933) decision of the English Court of Appeal in the case of Feist $v$. Société Intercommunale Belge d'Electricité."s This is the first case to be decided in England, since the pound went off the gold standard, involving the construction of a gold clause closely patterned on the gold clauses in American loan agreements.

The facts of the case were as follows. The plaintiff, a holder of one of the defendant's bonds, sought a declaration of his rights under the payment provisions of the bond providing that "The company . . will . . pay to the bearer .. . in London, England, . . . the sum of $£ 100$ in sterling or gold coin of the United Kingdom of or equal to the standard of weight and fineness existing on the 1st day of September, 1928." A similar provision for payment of interest followed. On the back of the bond appeared the statement that the bonds "are declared to be the direct and unconditional liability and obligation of the company in sterling or gold coin of the United Kingdom in accordance with the provisions of the bonds and these conditions." One of the conditions was that the bond would be construed according to the law of England. Each coupon stated the amount payable as £2.15.0. At the time the case was decided, sterling was at a discount of about $30 \%$ of par. The plaintiff sought two declarations in the alternative: first, that the company was obligated to pay in gold coin and was liable for damages if it failed to do so; or, second, that it should pay "such a sum in sterling as may be sufficient to purchase in the market on the day of payment gold of not less weight and fineness than that contained in the gold coin of the United Iingdom which would have

52. See the fuller discussion under The Effect of Impossibility to Procure Gold Coin, infra p. 1079.

53. Transcript of the proceedings before Mrr. Justice Farwell, Court of Chancery, October 27, 1932; transcript of Proceedings before 3iaster of the Rolls Lord Hanworth, Lord Justice Lawrence and Lord Justice Romer, Court of Appeal, March 17, 1933. See Comment by Bitchell and Bosmelet (1933) 60 Journar DU DroIT InTERnationale 170. The authors criticize the decision of Justice Farwell primarily on the ground that it is contrary to the view adopted by French, Swiss and Italian Courts and the decisions of the Hague Court of International Justice. It is impossible in the narrow scope of this article to survey the Continental jurisprudence with respect to the gold clause, which, being based upon a different principle and involving a difierent type of gold clause than here considered, is not directly pertinent to this study. 
been sufficient to discharge such payment if falling due on 1st September 1928."

In refusing to grant either declaration, Justice Farwell, in the decision of the Court of Chancery, insisted that the bond was a contract to pay money in a particular way and was not an obligation for the delivery of bullion. An obligation to pay $\$ 100$ could under the Coinage Act ${ }^{54}$ be satisfied by tendering $\$ 100$ in whatever was legal tender at the time; and, in the same way, the obligation expressed in each coupon to pay $\$ 2.15 .0$ was discharged by paying this sum in legal tender, and in fact could not have been paid at any time in gold coin, as provided in the agreement, since no gold

54. The following is a summary of British legislation respecting coinnge. Under Lord Liverpool's Act, 56 GEo. III, c. 68, (1816), gold coin alono was legal tender, except that silver could be used for that purpose up to 40 shillings. Under the Act of $3 \& 4$ WILL. IV, c. $98, \S 6$ (1833), notes of the Bank of England were made legal tender for all sums above $£ 5$ "so long as the Bank of England shall continue to pay on demand their said notes in legal coin." By the Coinngo Act 1870,33 \& 34 VIcr. c. 10, § 6 (1870), "Every contract . . . security for money, and every transaction, dealing, matter and thing whatever rolating to money, or involving the payment of, or the liability to pay any monoy . . . shall be made, executed, entered into, done, and had according to the coins which are current, and legal tender in pursuance of this Act and not otherwise." Under the Act of 4 \& 5 GEo. V, c. 14 (1914), Treasury notes for \&1 and 10 shillings were made current in the United Kingdom "in the samo manner and to the same extent, and as fully, as sovereigns and half soveroigns are current, and shall be legal tender in the United Kingdom for the payment of any amount." The limitation that Bank of England notes should bo legal tender only so long as the Bank of England continued to pay on domnnd their notes in legal coin was withdrawn in 1925 , by the Act of $15 \& 16$ GEo. V, c. $29, \S 1(1)$, and thenceforth banknotes were legal tender unconditionally. \& 1(2) provides: That the Bank of England shall be obliged to buy and soll gold bars at the rate of three pounds, seventeen shillings and tenpence halfpenny per ounce troy of gold of the standard of fineness prescribed for gold coin by the Coinage Act. Under $\S 1(1)$ the right to convert notes into coin was suspended. In 1928 the Treasury ceased to issue notes. Under the Act of 18 \& 19 GEo. V, c. $13, \S 1(2)$, the notes of the Bank of England in donominations of $£ 1$ and 10 shillings were made legal tender for the payment of any amount. Under $\S 11$ of the same Act, the Bank of England was ompowered "With a view to the concentration of the gold reserve and the securing of economy in the use of gold" to call for the return of gold owned by any person, and to sell it to the Bank "on payment therefor by the Bank in tho case of "coin, of the nominal value thereof." The Gold Standard Act (Amondment) of September, 1931, $21 \& 22$ Gro. V, c. 46, § 1(1) (1931), states: "Unless and until His Majesty by Proclamation otherwise directs, subsection (2) of section one of the Gold Standard Act, 1925 [providing that the Bank of England shall be obliged to buy and sell gold bars at the specified rate], shall cease to have effect, notwithstanding that subsection (1) of the said section remains in force." 
coin existed with which a 15-shilling payment could be made. 5 The plaintiff's contention that the bond required the payment of such $a$ sum as represented $£ 100$, measured by the value as to weight and fineness of the golden sovereign on September 1, 1928, however, would involve the payment of more than $\$ 100$ legal tender of the present day. Justice Farwell defined the dilemma before the court arising out of this clause as follows:

"Either I must give some meaning other than its proper meaning to the words 'One Hundred Pounds,' or I must give no real meaning to the last part of the first paragraph of the bond itself."

He saw no way, he said, of making the words consistent.

It was conceded that the attempt to provide for payment in gold coins only was not illegal, and that the debt could be satisfied by payment in gold coins. Since under the existing monetary laws both paper and metal were legal tender, however, the attempt to enforce payment in a particular form of legal tender was deemed by the court "an attempt to do something which cannot be enforced if the contract is a mere contract for the payment of money." "s A contract for the delivery of gold bullion, which the contract in question was not, could, however, be enforced by an action for damages. The court viewed the suggested construction of the obligation of the bond as one calling for some sum which was not in fact $£ 100$, but an unascertained sum which could only be ascertained at the time the payment was to be made, as an extremely difficult construction to adopt. In rejecting it, the court admitted that it was giving no effect to the words "in gold coin."

On appeal to the Court of Appeal, , the two declarations asked for in the alternative were somewhat modified. First, the appellant asked for such a sum in sterling in addition to the nominal amount in sterling mentioned in the bond as would represent any decrease in the gold value of the nominal amount on the day of payment;

55. See Lane County v. Oregon, 74 U. S. 71, 75 (1868), in which the Court observed that a legal tender in United States notes of the precise amount of taxes due could not be made. Referring to the Legal Tender Acts maling United States notes legal tender for "all debts," the Court argued against a narrow interpretation of the words: "Coin was then, and is now, the only legal tender for debts less than one dollar ... It is mentioned only to show that the general words 'all debts' were not intended to be taken in a sense absolutely literal." Similarly, it might be argued that the words "in gold coin" must not be read literally as applied to the 15 shilling item.

56. A similar argument was made by Justice Bradley in his concurring opinion in the Legal Tender Cases, supra note 10, at 566, quoted infra p. 1090.

57. Note 53, supra. 
second, for gold coin equal to the standard of weight and fineness existing on September 1, 1928. The Court of Appeal reviewed the various statutes bearing upon legal tender ${ }^{58}$ and concluded that any obligation for the payment of money, or, briefly, any debt, was dischargeable with banknotes at their nominal value.

The Court in its consideration of the case added the fact that gold coins were not available at the time the debt was due. Gold coins were not being issued by the mint, and holders of gold coin might, under the statutes, be called upon to turn in their holdings at their nominal value. Nor could the obligation be construed as a commodity obligation to deliver a quantum of gold of a certain fineness. The whole agreement indicated it was a debt. The construction of the agreement as a commodity contract would be inconsistent with the provisions of the bond in which the obligation is "declared to be the direct and unconditional liability and obligation of the company in sterling in gold coin of the United Kingdom in accordance with the provisions of the bonds and these conditions" and with the redemption table in the bond. Furthermore, the obligation called for the payment of $£ 100$ in sterling in gold coin. The interpretation of the contract as a commodity contract would render the words "in sterling" of no effect. The Bronson case was distinguished on the ground that the Treasury notes issued by the United States Treasury in 1862 were discriminated against by the very law that authorized their issue, customs duties being dischargeable only in gold coin. The Court also stressed the fact that payment of gold coin was practicable at the time of the Bronson judgment and that there was in that contract no such term as "sterling" to create an ambiguity by alternatives. To summarize this line of thought distinguishing the Bronson case, there was neither actual impossibility of payment in gold coin, nor had the Legislature expressed the policy that all money obligations be discharged in legal tender notes, thus leaving open the door to the contracting of gold coin debts.

In a separate opinion, Lord Justice Lawrence emphasized the construction of the contract as a debt, as distinguished from an obligation to deliver a number of gold coins of a certain weight and fineness, the legal import of which would be an agreement to deliver a weight of standard gold. The Justice devoted his opinion to the contention of the plaintiff creditor that the gold clause did not merely stipulate the mode of payment, but the quantum of the company's obligation under the bond. The fact that gold coins were not generally in circulation at the time the bond was contracted, and that the coupons were not actually payable in gold by reason of the

58. Note 54, supra. 
odd number of shillings called for, were recognized as factors giving support to the contention. Only after some hesitation did the learned Justice confess that he was swayed to the belief that the principal money secured by the bond was the definite sum of $\$ 100$ sterling,

"and not an uncertain amount, to be ascertained on the day of payment by adding to the sum therein specified a further amount of sterling in the event of a decrease in the gold value of that specified sum."

Having reached the conclusion that the gold clause referred to the mode of payment, rather than to the question of the obligation, Lord Justice Lawrence argued that the gold clause

"does not and cannot ... prevent bank notes, which under the Acts of 1833 and 1928 are made legal tender, from being legal tender. The plaintiff, under the express terms of those Acts, is legally bound to accept bank notes in payment of the moneys secured by the bond, and upon such payment the indebtedness of the Company under the bond would be discharged and the obligation thereunder extinguished. . . . A contract that a debt shall be discharged by payment in gold coins (being one form of legal tender) cannot abrogate the enactment by the Legislature that the debt may be discharged by the payment of bank notes (being another form of legal tender)."

Lord Justice Romer, in his opinion, declared that Section 6 of the Coinage Act ${ }^{59}$ required that a contract to pay a sum of money must be treated as a contract to pay in coins of the United Kringdom, and that this "seems to render illegal a contract to exclude the provisions of the Act as to legal tender." For reasons of public policy, moreover, he contended, the debt should be dischargeable in any form of legal tender. The great confusion and public inconvenience of allowing contracts in specific forms of tender was stressed. Thus, if silver coin contracts were allowed, there would be a risk of diminishing the silver coinage available for the public at large, and of imposing upon the mint the necessity of coining more.co The Justice declared that by reason of such illegality of the gold clause, the contract must be treated as though the gold clause were excluded.

Aside from the technical distinction between the facts of the Bronson case and those of the Feist case, in that the English bond called for $\$ 100$ in sterling in gold coin-words which introduced ambiguity by alternatives-, the two factual situations are clearly distinguishable on the ground that it appeared to be impossible to

59. Ibid.

60. In this connection Lord Justice Romer referred to the instance in 1919 when the price of silver rose to a point where the metal in a half crown (23. 6d.) was worth $3 \mathrm{~s} .41 \% \mathrm{~d}$. 
procure gold coin in England and that the British Coinage Act 01 made all British currency, unlike American currency, of equal power as legal tender, regardless of whether it was gold or paper. But the English Court, in rejecting the bullion theory and declaring that an obligation to pay more than the nominal amount of the debt in legal tender would not be implied, ${ }^{62}$ did not in any way depart from the doctrine of those Supreme Court cases which have hesitated to render judgments in legal tender with a premium over the nominal amount and, acting upon the dual currency theory, have insisted that the gold clause contract be enforced in coin for the nominal amount. ${ }^{63}$ If, therefore, the rationale of the bullion analogy in the

61. Note 54, supra.

62. On this point the Feist case is not without parallel in the United Strates. In Brown v. Welch, 26 Ind. 116 (1866), prior to the decision of the Bronson case, an obligation payable in gold coin was held discharged by a paymont in notes. The court argued, at 118, that the law made the legal tender equivalent for discharge of debts to the gold dollar and a failure to pay gold "cannot possibly beget an obligation to pay a greater sum in legal tender notes." Othor state courts also had passed on specie or gold coin contracts in the samo sonso. In Schoenberger v. Watts, $10 \mathrm{Am}$. L. Reg. 553 (Pa. 1862), the District Court of the City of Philadelphia set aside an attachment requiring the sheriff to levy "on specie, current gold and silver money," and pronounced itself strongly opposed to recognizing " $a$ debt of a new and special nature, not caprblo of being discharged in the way in which ordinary debts are by law payable." Semble, Warnibold v. Schlicting, 16 Iowa 243 (1864); Whetstone v. Colley, 36 III. 328 (1865); Galliano v. Pierre, 18 La. Ann. 10 (1866); Wilson v. Morgan, 4 Robt. 58 ( $N_{2}$ Y. 1866); Appel v. Woltmann, 38 Mo. 194 (1866); Reinback v. Crabtree, 77 Ill. 182 (1875); Schollenberger v. Brinton, 12 Am. L. Reg. 601 (Pa. 1864).

63. Here, too, the English case does not diverge radically from the Supremo Court cases which, until the decision of Gregory v. Morris, infro, nover roquired the payment of a premium in legal tender for a gold coin dobt. In Bronson v. Rodes, supra note 1 , judgment was rendered in coin; in Butlor v. Horwitz, supra note 45, the Court reversed a judgment of the lower court in legal tender with a premium for the difference in the value botween gold and legal tender. Also see Deming v. Sears, 78 U. S. 379 (1870); Currier v. Davis, 111 Mass. 480 (1873). In Gregory v. Morris, 96 U. S. 619 (1877), the action was for damages for wrongful replevin of certain cattle, the purchaser of which had promised to pay a certain sum in gold coin. The Court declarod the original contract was within the doctrine of the Bronson case, but hold that damages for the wrongful replevin need not be awarded in gold coin as a matter of law even though the measure of the wrong was gold coin. It appeared in the decision that the plaintiff had agreed to take legal tender. Following this case, the Supreme Court in United States v. Erie Railway Co., 106 U. S. 327 (1882), rehearing denied, 107 U. S. 1 (1882), held that a tax on interest payments was dischargeable in legal tender (actual equivalent of the gold percentage) where the payment taxed was a gold payment. It is not felt that these two cases are inconsistent with the Bronson case or that they weaken the position adopted by the Supreme Court with respect to gold 
Bronson case presented above is accepted, there is no real conflict between the two cases with respect to the guiding principles of interpreting a contract calling for a sum of money in gold coin as a debt dischargeable in its face value in currency.

\section{(B) The Effect of Revalorization of the Gold Dollar and the "weight and fineness" Clause.}

The exercise by Congress or by the President of the power given under the Thomas Amendment os to reduce the gold weight of the dollar, would raise a most interesting question in connection with

coin contracts. Statutes were enacted in some states specifically authorizing the courts to grant judgments in the medium chosen by the contracting parties. Thus in California such an Act (Calif. Stat. 1863, p. 687) was held constitutional by the State Supreme Court. Carpenter v. Atherton, 25 Cal. 564 (1864).

64. The Farm Relief Bill, Part VI, $\S 34(\mathrm{~b}) 2$ provides that the President be empowered "By proclamation to fix the weight of the gold dollar in grains nine-tenths fine at an amount that he finds is necessary from his investigation to protect the foreign commerce of the United States against the adverse effect of depreciated foreign currencies or in case the government of the United States enters into an agreement with any government or governments under the terms of which the ratio between the value of gold and other currency issued by the United States and by any such government or governments is established, the President may fix the weight of the gold dollar in accordance with the ratio so agreed upon and such gold dollar, the weight of which is so fixed, shall be the standard unit of value, and all forms of money issued or coined by the United States shall be maintained at a parity with this standard and it shall be the duty of the Secretary of the Treasury to maintain such parity, but in no event shall the weight of the gold dollar be fixed so as to reduce its present weight by more than 50 per centum."

The debate in the Senate on the Thomas Amendment, 77 Corc. REC. (No. 37) 2400 et seq. (April 26, 1933), indicated that the primary intent of the bill authorizing the President to reduce the statutory gold content of the dollar is to lift commodity prices and thus make the payment of taxes and debts easier. With regard to the effect of the reduction of statutory gold content upon the enforcement of gold clause debts, the sponsor of the Bill, Senator Connally, expressed the greatest doubt. "I, of course, do not know what the Supreme Court would decide about that ... All the Senate can do is to perform its duty as it sees it, either by reduction of the gold content of the dollar as it sees fit, or by increase of the gold content of the dollar, and then each citizen is relegated to the courts to find where that places him with respect to some particular contract." (2407). He did not contend that the Government should force its creditors to take the depreciated gold dollar (2409), but declared that "... there is quite a different question involved when two corporations are concerned, one owing the other holding the gold bonds ... When they make a contract stipulating that the bond must be discharged in dollars of a stipulated standard of weight and fineness, they make that contract with their eyes wide open, knowing that the Congress of the United States has, not alone today but has had from the beginning, the power to regulate the value of that money and change it whenever conditions warrant it." (2409). 
the amount of any payment due under a gold clause obligation. Creditors may contend that the gold clause entitles them to a pro rata increase in the amount payable equivalent to the decrease in the gold content of the dollar. On the bullion theory of the gold clause, this contention should prevail in the absence of any further restrictive legislation. If the bullion theory is not adopted, however, a very different result may follow. Moreover, if the gold clause is virtually read out of the contract by legislation, the change in the gold content of the dollar would have no effect upon the quantum of the obligation in terms of dollars.

No legal controversies appear to have reached the higher state or federal courts involving questions raised by the reduction of the gold content of the dollar in 1834. ${ }^{\text {O5 }}$ The Supreme Court did, however, briefly discuss this revalorization of the gold dollar in the Legal Tender Cases. Justice Strong declared that an obligation to pay $\$ 1,000$, contracted before 1834 , could "undoubtedly be discharged with 100 eagles coined after that date," though they contained less gold than eagles coined previous to the Act. The general theory which controlled this situation was expressed by him as follows: “. . . contracts for the payment of money are subject to the authority of Congress, at least so far as relates to the means of payment. They are engagements to pay with lawful money of the United States, and Congress is empowered to regulate that money." 60

The effect of the reduction was that all creditors were subjected to a proportionate loss in the gold value of their claims.

"The creditor who had a thousand dollars due him on the 31st day of July, 1834 (the day before the act took effect), was entitled to a thousand dollars of coined gold of the weight and fineness of the then existing coinage. The day after, he was entitled only to a sum six per cent. less in weight and in market value, or to a smaller number of silver dollars. Yet he would have been a bold man who had asserted that, because of this, the obligation of the contract was impaired, or that private property was taken without compensation or without due process of law. No such assertion, so far as we know, was ever made." or

Senator Connally contended, moreover, that since the power to detormino what is legal tender is vested in Congress, this excludes the power of privato individuals to say by contract what shall be legal tender (2406, 2407). "I do not believe that private individuals have any right to undertake to fix a standard of money by contract, and were I to have my way, I should enact a law providing that thereafter private individuals should not make contracts except in the standard, lawful money of the United States." (2411).

65. Act of June 28, 1834, 4 STAT. 699.

66. Supra note 10 , at 549 .

67. Id. at 552 . 
It is to be presumed, however, that in this dictum Justice Strong was referring to obligations calling for the payment of $\$ 1,000$ without further qualification. With respect to bonds containing a clause calling for payment in gold coin of the United States of or equal to the standard of weight and fineness existing on a certain date, this dictum is not controlling. To what extent such a clause succeeds in accomplishing the result of protecting the creditor, in the event of a revaluation of the dollar at a lower gold content, has never been clearly decided by an American court. The clause may, however, be analyzed with a view to determining just what it purports to provide.

The gold content of the dollar is fixed by statute as $258 / 10$ grains of gold 9/10 fine.6s Under the first alternative of the clause quoted above, "of . . . the standard of weight and fineness existing" on a certain date, it appears clear that gold coins of a specific type of minting, in accordance with the date inserted in the agreement, are required. If at the time of payment this type of minting is the only one in existence, then the clause is mere surplusage over the simpler "\$1,000 in gold coin" clause. If, on the other hand, such coins are not the only type existing, but co-exist with coins (also dollars) of a different weight and fineness, as may have been the case following the 1834 revalorization, then the creditor might insist, on the strength of the Bronson case, that the debt be paid in the type of dollars specified in the agreement.co But if we assume that the new coins of lesser gold content were completely to replace the "old type" coins, a very difficult question would be raised. Would the creditor be entitled to an amount in gold weight of the new coins equivalent to the weight of the coins called for by his contract? No answer to this question can be found in the authorities. If the Bronson case is read as holding a gold coin contract to be in substance a commodity contract, it might be successfully contended that the payee was entitled to damages equal to the value of the bullion in the gold coins stipulated in his contract. If, however, the decision in that case is construed as holding that the obligation was a debt payable in an existing and recognized form of currency, then a different result might follow.

The words of alternative, "of or equal to," in the "weight and fineness" clause, appear on close examination to call for the same thing, namely, gold coin as it existed on the stated date. $\$ 1,000$ in gold coin of the United States equal to the standard of weight and

68. 17 StaT. 426 (1873), 31 U. S. C. $\S 315$ (1926).

69. The reasoning would follow closely the dual currency theory reasoning discussed supra, p. 1064 et seq. 
fineness existing on a certain date, can scarcely be paraphrased to read: "That amount of gold coin the weight and fineness of which will equal the weight and fineness of one thousand dollars nominal amount of gold coin existing on the stated date." In the actual clause the definite amount relates to gold coin to be paid; in the paraphrased clause it relates to the coin which measures the debt, not to the coin of payment, the amount of the latter being wholly uncertain. It would require a great straining of the logical faculties of the Court to accept such a construction. The Court of Appeal, in the Feist case, in referring to the words "of or equal to," declared that they were "mere surplusage" and added: "A thing that is of a ton weight must be of a weight equal to a ton."

In Murray v. Harrison ${ }^{70}$ (1867), the New York Supreme Court had before it a clause reading: ". . . . in gold and silver coin of the standard by which the coins of the United States were regulated by the laws existing on the 20th day of May, 1846, the sum of $\$ 4,000 . "$ The court held, the case having arisen prior to the Bronson case, that the debt was dischargeable with the face amount of legal tender. In discussing the clause, the court declared:

"Of course it follows if the legal tender act had not been passed, but congress, after the date of the bond, had materially debased, or lowered the standard of gold and silver coin, that the plaintiff would have been obliged to receive payment of her debt, in such debased gold or silver coin, by tale or count; that her debt could have been paid in any gold or silver coin, at its then regulated standard or value, as coin or money, which was or might be a legal tender for such a sum or amount of money. It is plain that this result would have followed from the very terms of the contract, and without reference to the considerations that it was the evident intention of Bronson, to whom the bond was executed, as executor, by the contract, to protect the estate under his charge, against the power of congress to regulate the value of coins, of course to debase them, and that no court could aid a party in thus undertaking by contract, to thwart or evade a conceded power of congress." 71

In Brown v. Welch ${ }^{72}$ (1866), the contract before the Indinn court called for a certain sum in gold "or, if paid in paper, the amount thereof necessary to purchase the gold at the place of payment." Inasmuch as the case was argued before the Bronson decision, the court did not award judgment in gold coin. In considering the effect of the added provision in the contract quoted above, the court argued that the stipulation to pay paper currency enough to buy

\footnotetext{
70. 47 Barb. 484 (N. Y. 1867).

71. Id. at 493 .

72. 26 Ind. 116 (1866).
} 
the specified sum in gold "means nothing; for such a sum of paper as would purchase ingots worth, say, $\$ 500$ would simply be that sum in paper. There would be no premium possible."

In Butler v. Horwitz ${ }^{73}$ (1868), the debt was measured in foreign coin of a certain weight "and other gold and silver at their present [1791] established weight and rate according to Act of Assembly, on the 1st day of January in each and every year during the continuance of the present demise." 74 This was construed by the Supreme Court as a bullion contract, for the breach of which damages must be assessed in gold coin. This case is distinguishable from the others cited above in that foreign gold coin may well be regarded as bullion for purposes of any judgment relating thereto.

It thus appears that none of the cases cited upholds the "of or equal to" clause as entitling the creditor to more than the face amount of the debt, although under the Bronson case, of course, judgment might be rendered in gold coin. If the dollar figure is construed as measuring the debt, and the coin clause is construed as being purely descriptive, then this descriptive clause cannot at the same time be construed as controlling the nominal amount of the debt. It must be conceded, however, that no authoritative American case has been found squarely upholding this view.

(C) The Effect of Legal Impossibility to Procure Gold Coin

Neither in the Bronson case nor in any other Supreme Court case has there been raised any question of the effect upon gold clause contracts of impossibility to secure gold coin, inasmuch as such coin has apparently always been available in the United States. It has already been indicated, on the other hand, that the impossibility in the Feist case of acquiring gold coin was adduced by the English Court as one of the grounds for its decision. A similar defense of impossibility was raised in a notable Canadian decision, American Chicle Co. v. Somerville Paper Box Co. ${ }^{75}$ In this case the plaintiffs held a mortgage which provided that it would be void "on payment in current gold coin at the option of the mortgagees of $\$ 75,000$ of lawful money of Canada. . .." The question was whether the plaintiffs were entitled to exact payment in gold coin, or payment of so much Canadian or American currency as would secure gold coin to the amount of the debt. The Court found that gold was unprocurable in Canada ${ }^{70}$ and concluded that

73. Note 45, supra.

74. Id. at 259 .

75. 50 Ont. L. R. 517 (1921).

76. The Currency Act, Stat. of CaN., 9 \& $10 \mathrm{EdW}$. VIr, c. 14 (1910), assented to May 4, 1910, provided that American gold coins should pass cur- 
". . . it has become legally impossible for a debtor to discharge his obligation in Canada in gold coin made in Canada or to procure it for the purpose of exportation to the United States in payment of a debt which under the circumstances of the case may become payable in that country. Indeed, my view of the legislation and the orders in council pursunnt thereto is, that they nullify or suspend for the time being the bencfit of the exercise of the option given to these mortgagees ... . or rather prevent the debtor from complying with it and enable him to discharge his debt in money which is legal tender in this country." 77

The effect of this decision is to read an option into the contract to pay in legal tender if gold coin becomes unprocurable. In this result the Chicle case does not appear to be in conflict with the Feist case, assuming that there was real impossibility in the latter. Both impose the risk of impossibility of procuring gold coin upon the creditor, in that all he got in each case was legal tender in the face amount of the debt. The facts of the Chicle case are distinguishable, of course, from those in the Bronson case, but the implication that a gold coin obligation would have been enforced had gold coin been procurable harmonizes with the holding of the United States Supreme Court.

Somewhat analogous to the above cases involving legal impossibility is a very old case taken to the Privy Council in $1760 .^{78}$ The question presented was the measure of value of a debt contracted in a currency which had ceased to exist at the time of judgment. The contract called for " $\$ 2460$ in good public bills of the Province of Massachusetts Bay, or current lawful money of New England, with interest." The New Hampshire court held tender of bills of credit current in New Hampshire sufficient to discharge the obligation. On appeal to the Privy Council Lord Mansfield declared that he was at a loss to know by what rule to proceed in determining the quantum of the debt, since the Province bills contracted for were called in and gone and the contract, by specifically refering to the bills of credit, clearly required these in contradistinction to

\footnotetext{
rent and be a legal tender in Canada for their face value, and that overy contract and every transaction relating to money or involving the pnymont of money was to be made according to the coins made for circulation in Canada and which were current and legal tender in pursuance of the Act, unless the same be made according to the currency of Great Britain or of some British possession or some foreign state. Ibid. § 15 (3). The Act also provided that gold and paper currency were legal tender. Redemption of Dominion notes in specie was suspended on August 10,1914, prior to the due date of the obligation. The court rejected the contention that the debt must be discharged in American gold coin, as the contract called for payment to be made in Canada.

77. Supra note $\mathbf{7 5}$, at 522 . (Italics supplied).

78. Deering v. Parker, 4 Dall. (App.) xxiii (Pa. 1760).
} 
the bills of credit of any other colony. The Court, in order to determine the usage in the American colonies in cases of this hind, consulted with an expert who declared that after the "old tenor" "had been called in and sunk" judgments were given in the colonies in "real money," but that the question of how much to give "was greatly agitated." The more general method, he said, was to take the value of the bills when they should have been paid and give judgment in what was then tender. Lord Mansfield, while approving the rule as one of right, in general refused to apply it inasmuch as

sthe currency of the country, had, in the meantime, sunk gradually, and become in some measure, everyone's loss and that, therefore, in this case, he thought the loss ought to be divided between them."

Instead of computing the debt at the rate of 27 shillings to the ounce, the price of silver at the time of payment, the value was fixed at 37 shillings and the debt was computed at about 100 pounds sterling. The case illustrates the very grave difficulty of computing the value of debts contracted in currency that has ceased to become available.

In a recent case there was presented the interesting question of what would be the effect upon the rights of the parties of illegality of a gold clause in a municipal bond. The defendant sought an injunction restraining a suit on the bonds, contending that the bonds were null and void because they provided for payment in gold coin of the United States of the present standard of weight and fineness, while the decrees validating their issue merely authorized the district to sell bonds in dollars. The Circuit Court of Appeals sustained the lower court's denial of the injunction, stating that

s'Only that feature of the issued bonds properly could be regarded as unauthorized. The result of that provision of the issued bonds bcing unenforceable would not be to render those bonds unenforceable in so fant as the provisions thereof were legally authorized. An effect of the quoted provision of the issued bonds being adjudged to be inzalid in a suit thereon would be that a judgment in favor of the plaintiff in such suit would be entered for dollars and parts of dollars, without further specifying what was payable under the judgment. Bronson v. Rodes, 7 Wall, 229, 254, 19 L. Ed. 141. Under existing conditions it seems that a judgment in the form indicated in the suit, the prosecution of which was sought to be enjoined, would not be substantially different from a judgment calling for dollars and parts of dollars in gold coin of the weight and fineness provided for by law at the time the bonds were authorized and issued." 70

79. Greene v. Uniacke, 46 F. (2d) 916, 919 (C. C. A. 5th, 1931), cert den., 283 U. S. 847 (1931). (Italics added). 
Since the theoretical problems raised by legal impossibility of procuring gold coin are not very different from those raised by illegality of promising payment in coin, this decision is very suggestive.

The Governmental Regulations enacted since March 6, 1933 have now directly raised in the United States this question of the effect of impossibility of paying out gold coin in discharge of gold coin debts. Banking institutions were prohibited by the Presidential Proclamation of March 6, 1933 from paying out or permitting the withdrawal or transfer of gold coin or bullion, or taking any other action which might facilitate the hoarding thereof. ${ }^{80}$ This Regulation is still in force. By the Act of March 9, 1933,81 the President

80. The President's proclamation of March 6, 1933 (Federal Reserve Bank Circular No. 1166) declaring a bank holiday provides:

"During such holiday, excepting as hereinafter provided, no such banking institution or branch shall pay out, export, earmark or permit the withdrawal or transfer in any manner or by any device whatsoever of any gold or silver coin or bullion or currency, or take any other action which might facilitato the hoarding thereof . .." On March 9, 1933 the provisions of this proclamation were extended "until further proclamation by the President" (Fedoral Reserve Bank Circular No. 1172).

81. The Act of March 9, 1933 (Federal Reserve Bank Circulnr No. 1171) provided in Title I, Sec. 1, that the proclamations theretofore issued by tho President were approved; Sec. 2 provided:

"(b) During time of war or during any other period of national omorgency declared by the President, the President may, through any agency that he may designate, or otherwise, investigate, regulate, or prohibit, under such rules and regulations as he may prescribe, by means of licenses or otherwise, any transactions in foreign exchange, transfers of credit between or payments by banking institutions as defined by the President, and export, hoarding, melting, or earmarking of gold or silver coin or bullion or currency, by any person within the United States or any placo subject to the jurisdiction thereof; and the President may requiro any person engaged in any transaction referred to in this subdivision to furnish, under oath, complete information relative thereto, including the production of any books of account, contracts, letters or other papers in connection therewith in the custody or control of such person, either beforo or after such transaction is completed."

The penalties for violations of this provision are a fine of $\$ 10,000$, or imprisonment for ten years, or both.

Sec. 11 of the Federal Reserve Act was amended by the addition of the following:

"(N) Whenever, in the judgment of the Secretary of the Treasury, such action is necessary to protect the currency system of tho United States, the Secretary of the Treasury, in his discretion, may require any or all individuals, partnerships, associations and corporations to pay and deliver to the Treasurer of the United States any or all gold coin, gold bullion and gold certificates owned by such individuals, partnerships, associations and corporations. Upon receipt of such gold coin, gold bullion or 
was authorized to regulate or prohibit the export, hoarding, melting or earmarking of gold coin or bullion, and the Secretary of the Treasury was authorized to require that all individuals, partnerships, associations and corporations deliver to the Treasury of the United States any or all gold coin or bullion owned by such individuals in payment therefor" of "an equivalent amount of any other form of coin or currency coined or issued under the laws of the United States."

By Executive Order dated April 5, $1933{ }^{82}$ all persons and corporations were required to deliver gold coin owned by them to the

gold certificates, the Secretary of the Treasury shall pay therefor an equivalent amount of any other form of coin or currency coined or issued under the laws of the United States.

"The Secretary of the Treasury shall pay all costs of the transportation of such gold bullion, gold certificates, coin or currency, including the cost of insurance, protection and such other incidental costs as may be reasonably necessary.

"Any individual, partnership, association or corporation failing to comply with any requirement of the Secretary of the Treasury made under this sub-section shall be subject to a penalty equal to twice the value of the gold or gold certificates in respect of which such failure occurred and such penalty may be collected by the Secretary of the Treasury by suit or otherwise."

82. The Executive Order issued by the President on April 5, 1933 is entitled "Forbidding the Hoarding of Gold Coin, Gold Bullion and Gold Certificates" and provides that, under the existing emergency, the President has prohibited "the hoarding of gold coin, gold bullion and gold certificates within the continental United States by individuals, partnerships, associations and corporations", and prescribes certain regulations for carrying out the purposes of the order.

Under Sec. 2 of the order, all persons are required "to deliver on or before May 1, 1933, to a Federal Reserve Bank ... all gold coin, gold bullion and gold certificates now owned by them or coming into their ownership on or before April 28, 1933", except gold required for (a) "legitimate and customary use in industry, profession or art"; (b) gold coin and gold certificates in an amount not exceeding in the aggregate $\$ 100$ belonging to any one person; (c) gold coins having a recognized special value to collectors of rare and unusual coins; (d) gold coin and bullion earmarked or held in trust for a recognized foreign government or foreign central bank or the Bank for International Settlements; (e) gold coin and bullion licensed for other proper transactions (not involving hoarding).

It is provided in Sec. 3 that any person becoming the owner of any gold coin, gold bullion or gold certificates after April 28, 1933 shall, within thres days after receipt thereof, deliver the same in the manner prescribed in Sec. 2 , unless it fall with the exceptions set forth in said Sec. 2.

Sec. 4 provides that, upon receipt of the gold coin, gold bullion or gold certificates, the Federal Reserve Bank will pay therefor an "equivalent amount of any other form of coin or currency coined or used under the laws of the United States."

Under Sec. 8, the Secretary of the Treasury is authorized to issue licenses permitting the Federal Reserve Banks, "in return for an equivalent amount 
Federal Reserve Banks "in return for an equivalent amount of other coin, currency or credit." An exception was made with respect to holdings under $\$ 100$, collectors' coins, gold held for professional or industrial uses, gold earmarked for a recognized foreign government or foreign central bank or the Bank of International Settlements, and gold held under license issued by the Secretary of the Treasury. ${ }^{83}$ It is further provided in Section 3 of the Order that

of other coin, currency or credit, to deliver, earmark or hold in trust gold coin and bullion to or for persons showing the need for the same" for any of the purposes specified in Sec. 2.

Sec. 9 provides for a fine of not more than $\$ 10,000$ and imprisonmont of not more than ten years for violations of this order.

83. On April 29, 1933, the Secretary of the Treasury issued detailed Regulations Relating to Licensing the Purchase and Export of Gold (Federal Reserve Bank Circular No. 1220), Art. V of which provides as follows:

"Sec. 1. Licenses for Proper Transactions and for Purposes not Covered in Preceding Articles. Any person showing the need for gold coin or gold bullion for a proper transaction not involving hoarding or for gold coin or gold bullion for a purpose specified in the Executive Order of April 5, 1933, and not covered by the foregoing Articles of these Regulations, may make application to the Secretary of the Treasury for a license to purchase, or if such coin or bullion is already in his possession to retain such coin or bullion, in amounts as may be reasonably necessary for such proper transaction or purpose. Applications shall be filed with any Federal Reserve Bank. . .."

Sec. 2 provides for investigation of each application by the Fedoral Reservo Bank and transmittal to the Secretary of the Treasury with supplemental information and recommendations.

"Sec. 3. Granting or Denial of the License. Upon receipt of the original application and the recommendation of the Federal reserve bank transmitting; it, the Secretary of the Treasury will grant or deny the license. A licenso will be granted on application for the retention or acquisition of gold coin or bullion made by any person showing the need for such gold coin or bullion in accordance with the provisions of section 8 of the Executive Order of Aprit 5 , 1933, in cases where such person has gold coin, gold bullion or gold certifcates in his possession, or in obedience to said Executive Order, has delivered such coin, bullion or certificates. A license so granted shall be for an amount of gold coin or bullion not exceeding the amount of such coin, bullion or cortificates held or delivered. . . .

"Sec. 4. Acquisition of Gold. Upon presentation of a license for the acquisition of gold coin or bullion to a Federal reserve bank, such bank shall deliver to the licensee the amount of gold coin or gold bullion authorized in such license upon payment therefor in an equivalent amount of any form of coin or currency coined or issued under the laws of the United States.

"Sec. 5. Reports Required on the Disposition of Gold Coin or Bullion. Any person holding a license for the retention or acquisition of gold coin or bullion issued under this Article, who shall at any time dispose of such gold coin or bullion in accordance with the terms of the license or otherwise, shall immodiately file a written report in duplicate with the Federal reserve bank through which the license was issued...." 
all recipients of gold coin or bullion are obligated to deliver it to a Federal Reserve Bank within three days of its receipt, unless they come within the exceptions noted above. While payment of gold coin by private individuals or corporations other than banking institutions is not restrained by this Order, it is practically impossible for the payor who must meet maturing gold coin bonds to obtain the necessary gold in the United States, unless licenses are issued by the Secretary of the Treasury. Moreover, restrictions on dealings in foreign exchange would appear to make the purchase of gold abroad also practically impossible. ${ }^{84}$

Under an unpublished ruling of the Undersecretary of the Treasury, dated April 29, 1933, the governor of the Federal Reserve Bank of New York was informed that until further notice the Secretary of the Treasury will grant no licenses for the acquisition of gold, gold coin, or bullion by persons maling application for the same under the Executive Order of April 5, 1933, for the purpose of meeting maturing obligations calling for payment in gold coin or bullion, within the United States or elsewhere, except where such applicants have surrendered gold coin, gold bullion or gold certificates in obedience to the Executive Order of April 5, 1933.

84. Transactions in foreign exchange were regulated by the Executive Order of Miarch 10, 1933 (Federal Reserve Bank Circular No. 1176, March 12, 1933), which prohibited all transactions in foreign exchange, except such transactions as may be undertaken (a) for legitimate and normal business requirements, (b) for reasonable traveling and other personal requirements, and (c) for the fulfillment of contracts entered into prior to March 6, 1933. Dealers in foreign exchange were required to obtain from each person to whom they cell foreign exchange, directly or indirectly, a written declaration signed by such person describing the purpose for which the foreign exchange is purchased and certifying that the transaction in no way contravenes the Act of March 9, 1933, the Executive Order of March 10, 1933, or any regulation issued thereunder, and to file with the Federal Reserve Bank written reports which will show the foreign exchange position of such dealers at any given time.

In a subsequent Executive Order under date of April 20, 1933 (Federal Reserve Bank Gircular No. 1214, April 20, 1933), the President issued the following regulations:

"1. Until further order, the esrmarking for foreign acount and the export of gold coin, gold bullion or gold certificates from the United States or any place subject to the jurisdiction thereof are hereby prohibited, except that the Secretary of the Treasury, in his discretion and subject to such regulations as he may prescribe, may issue licenses authorizing the export of gold coin and bullion (a) earmarked or held in trust for a recognized foreign government or foreign central bank or the Bank for International Settlements, (b) imported for reexport, or gold in reasonable amounts for usual trade requirements of refiners importing gold bearing materials under agreement to export gold, (c) actually required for the fulfillment of any contract entered into prior to the date of this order, by an applicant who in obedience to the Executive Order of April 5, 1933 has delivered gold coin, gold bullion or gold certificates, and (d) with the approval of the President, for transactions which he may deem necessary to promote the public interest. 
So long as these Orders continue in force a court would not be hard pressed to find that there was legal impossibility of paying out

\footnotetext{
"2. Until further order the Secretary of the Treasury is authorized, through any agency that he may designate, to investigate, regulate, or prohibit, undor such rules and regulations as he may prescribe, by means of licenses or othorwise, any transactions in foreign exchange, transfers of credit from any banking institution within the United States or any place subject to the jurisdiction thereof to any foreign branch or office of such banking institution or to any foreign bank or banker, and the export or withdrawal of currency from tho United States or any place subject to the jurisdiction of the United States, by any individual, partnership, association or corporation within tho United States or any place subject to the jurisdiction thereof; and the Secretary of the Treasury may require any individual, partnership, association, or corporation engaged in any transaction referred to herein to furnish under onth, complete information relative thereto, including the production of any books of account, contracts, letters or other papers, in connection therewith in the custody or control of such individual, partnership, association, or corporation either before or after such transaction is completed.

" 3 . The provisions relating to foreign exchange transactions contrined in the Executive Order of March 10, 1933, shall remain in full force and offect except as amended or supplemented by this order and by regulations issued hereunder.
}

"4. Applicants who have gold coin, gold bullion or gold cortificates in their possession, or who in obedience to the Executive Order of April 5,1033 have delivered gold coin, gold bullion or gold certificates, shall be ontitled to licenses as provided in Section 8 of said Executive Order for amounts not exceeding the equivalent of such coin, bullion or certificates held or delivered. The Secretary may in his discretion issue or decline to issue any other liconses under said Executive Order, which shall in all other respects remain in full force and effect."

Under Paragraph 5 of the Order, violations thereof are made punishablo by a fine of not more than $\$ 10,000$ or imprisonment for not more than ten years.

Art. III of the Regulations Relating to Licensing the Purchase and Export of Gold, issued by the Secretary of the Treasury on April 29, 1933, provides as follows:

"Sec. 1. License Required. No gold coin, gold bullion or gold certificates shall be exported from the United States or any place subject to tho jurisdiction thereof, or earmarked for foreign account unless a license therofor shall first have been obtained from the Secretary of the Treasury in accoldance with this Article or Article IV of these regulations." It is then provided that "Licenses may be issued, in the discretion of the Secretary, authorizing the export of gold coin and gold bullion" in certain instances, those instances being a recapitulation of the ones set forth in Sec. 1 of the Executive Order of April 20, 1933, supra.

"Sec. 2. Application for Licenses. Application for license undor Section 1 to export from the United States or any place subject to the jurisdiction thereof any gold coin or gold bullion shall be made to the Secretary of the Treasury. ...."

Sections 3,4 and 5 deal with procedure in filing applications and in issuing licenses.

"Sec. 6. Notification of Issuance of License. At the time the license is issucd, the issuing Federal reserve bank shall transmit a copy thereof to the Collector 
gold coin. ${ }^{85}$ Moreover, under these facts the dual currency theory elaborated in the chain of cases starting with Bronson v. Rodes, in which the Supreme Court insisted on coin judgments being granted in gold coin contracts, is no longer applicable. If, therefore, it may be fairly assumed that judgments in gold coin will not be granted so long as these Orders remain in force, the courts will have to grant some other form of relief in passing on contracts containing the gold clause. The following are four possible alternatives available to the courts: (1) They may construe the debt as dischargeable in its face amount of legal tender; (2) They may construe impossibility of procuring gold coin as suspending the creditor's right to gold coin until the restrictions are removed; (3) They may give judgments for damages, payable in legal tender, for breach of the gold coin contract; (4) They may hold the contract frustrated and the creditor entitled to restitution. It is obvious that the amount of the recovery will depend upon which of these theories the courts adopt. The novelty of the situation and the uncertainty of the character of further legislation affecting gold clause contracts, render entirely speculative any conclusion as to which of these courses the courts will follow.

The gold clause which was generally inserted in bonds floated prior to the present financial crisis has proved to be unsatisfactory from the

of Customs at the port of export designated thereon. No collector of Customs shall permit the export of any gold coin or bullion under this Article except upon surrender of a license to export, a copy of which has been received by him from the Federal reserve bank issuing such license.

"Sec. 7. Expiration of License. All licenses to export gold coin or bullion issued under this Article shall expire fifteen days after date of issue and any person holding a license who fails to export gold coin or bullion in accordance with the terms of the license shall forthwith deliver such gold coin or bullion to a Federal reserve bank."

85. The general law of impossibility as an excuse for non-performance cannot be gone into in this article. Reference is made to the following authorities: Woodward, Impossibility of Performance as an Esceuse for Brcach of Contract (1901) 1 CoL. L. REv. 529; Page, The Developinent of the Doctrine of Impossibility of Performance (1920) is MICH. L. REv. 589; Corbin, Supcricning Impossibility of Performing Conditions Preccdent (1922) 22 COL. L. REv. 421, 422; 3 WILLISTON, Contracts (1920) § 1938; 2 Restatesient of the LaW of Contracts (Am. L. Inst. 1932) \$§ 457-8. And see Larabee Co. v. Crossman, 100 App. Div. 499, 92 N. Y. Supp. 565 (1st Dep't. 1905), aff'd, 184 N. Y. 586, 77 N. E. 1189 (1906). Perhaps the closest analogy to the facts here discussed is to be found in Prohibitions and Mandatory Legislation Enacted During the War. See Blair, Breach of Contract Due to War, SELEcTED REadings on THE LAW OF CONTRACTS (1931) 1015. The availability in an action for damages arising from breach of contract, of the defense of impossibility by reason of governmental regulations is discussed in Mawhinney v. Mrillbrook Woolen Mrills, Inc., 231 N. Y. 290, 132 N. E. 93 (1921). 
economic standpoint in that it has failed to stabilize the value of the debt, a failure resulting from the wide fluctuations in the value of gold during recent years. ${ }^{86}$ The clause now threatens to prove unsatisfactory from a legal standpoint as a means of insuring the creditor a recovery in gold coin or its market equivalent in currency. Moreover, if the American courts follow the Feist case, it is doubtful whether the gold clause can be rewritten so as to afford the protection desired. $^{87}$ In view of this uncertainty, it may not be inappropriate to discuss briefly some of the alternatives available to prospective borrowers and lenders who desire to secure adequate protection against fluctuations in the value of paper currency. The following forms of clauses are therefore discussed primarily with a view to determining whether any of them offers a practical solution of this problem.

\section{III}

\section{Gold Bullion Clauses}

Three types of gold bullion clauses as measures of debts may be distinguished: (1) An obligation to deliver bullion and nothing else; (2) An obligation to pay the equivalent of a certain weight of bullion in (a) coin or (b) legal tender; (3) An option in the promisee to demand a certain amount of bullion or currency in the form of coin or legal tender. Only the first type of bullion clause is a true commodity obligation, entitling the holder, upon failure to receive the commodity stipulated, to damages measured by the value of the commodity at the time and place of delivery. ${ }^{88}$ The first alternative of the second of these types has been viewed as equivalent in effect to a gold coin clause. In Sears v. Dewing ${ }^{80}$ (1870), the Supreme Court held an obligation calling for the payment of "four ounces two pennyweight and twelve grains of pure gold in coin money" to be

86. Note 20, supra.

87. Note 20, supra. A modification of the gold clause appeared in the advertisement by The Edison Electric Illuminating Co. of Boston of a now issue of notes. N. Y. Times, April 18, 1933, p. 23. This provides: "Principnl and interest payable in gold coin of the United States of America, if paymont in such gold coin is lawful at the time such payment becomes due."

88. In Clark v. Minor, $73 \mathrm{Ga} .590$ (1884), it was held that cotton notes entitle the holder on breach to the value of undelivered cotton at the time and place of delivery. And see Gilbreath v. Dilday, 152 Ill. 207, 38 N. E. 572 (1894); Wilson v. Morgan, 4 Robt. 58 (N. Y. 1866) (distinguishing a bullion from a coin contract).

89. 78 U. S. 379 (1870), rev'g 96 Mass. 413 (1867). In this case the Court construed the lease as requiring the payment of $\$ 20$ in gold coin a quirtor prior to 1834 , when the gold content of the dollar was diminished, and $\$ 21.31$ in gold coin a quarter thereafter. See also Butler v. Horwitz, supra noto 45. 
a contract for "a specified weight of pure gold solvable in coin money," and reversed a judgment in favor of the creditor for the legal tender value of the gold at the time of the breach. Under this decision a clause specifying weight and fineness of gold payable in coin is in no essential respect different from a payment clause calling for payment in gold coin, except that account may be taken in the judgment of the weight and fineness of the coin in which judgment is given. The second alternative of the second type of bullion clause, calling for the payment of legal tender, makes the obligation simply one for a sum of money to be determined by valuing the stated amount of gold at the time and place of payment. The use of this type of contract as the measure of a debt directly raises the question of the negotiability of the obligation. The third type of gold bullion clause, providing for an option in the payee, raises a very real practical difficulty. If the option is in the payee to demand either one of two kinds of performance, failure by the payee to exercise the option on the due date might enable the debtor to discharge the obligation by performance of either of the two alternatives.00 If the intention of drafting an obligation of this lind is to give to the payee the benefits of a bullion obligation, with all of the advantages of an obligation to pay an amount certain in money, the mechanical difficulty of preventing the option from shifting to the debtor may make such an obligation impractical, even though it be deemed negotiable by reason of such a stipulation. ${ }^{01}$

The dictum in the Bronson case analogizing the gold clause obligation to a bullion contract failed to note the distinction, which would become of importance in the event that legislation is enacted making

90. HUNT, op. cit. supra note 4, at 151; Johnson v. Seymour, 19 Ind. 24 (1862). If the time within which the payee may elect which of the two alternative types of performance he demands is limited, the option shifts to the obligor upon the expiration of this time. Townsend v. Wells, 3 Day R. 327 (Conn. 1809). But in the absence of special agreement the option is presumed to be in the payor. CHIPMAN, Law of Contracts for the Payares of Specifick Articles (1822) 35; Nipp v. Diskey, 81 Ind. 214 (1881). In Alarlor v. Texas \& P. R. Co., 21 Fed. 383, 385 (C. C. S. D. N. Y. 1884), where the option was in the payor, the court declared: "It is elementary that when a promise is in the alternative, to pay in money or in some other medium of payment, the promisor has an election either to pay in money or in the equivalent, and after the day of payment has elapsed without payment the right of election on the part of the promisor is gone, and the promisee is entitled to payment in money." An offer to accept payment at the rate of $51 / 2 \mathrm{c}$. gold or 9c. currency becomes an option of the payee after due date. Stephens v. Howe, 34 N. Y. Super. Ct. 133 (1873).

91. $\S 5(4)$ of the N. I. L. provides: "The negotiable character of an instrument is not affected by a provision which gives the holder an election to require something to be done in lieu of payment of money." And see Hosstatter $\nabla$. Wilson, 36 Barb. 307 (N. Y. 1862). 
gold coin debts dischargeable in legal tender, ${ }^{02}$ between a contract for the delivery of goods, notably gold, and a contract solvable in money by means of a count of certain coins. Justice Bradley, however, in his concurring opinion in the Legal Tender Cases, ${ }^{05}$ in the course of which he expressed himself as favoring a construction of the Legal Tender Acts as authorizing the discharge of gold coin obligations in legal tender, made a sharp distinction between a gold coin contract and a bullion contract:

"If the contract is for the delivery of a chattel or a specific commodity or substance, the law does not apply. If it is bona fide for so many carats of diamonds or so many ounces of gold as bullion, the specific contract must be performed, but if terms which naturally import such a contract are used by way of evasion and money only is intended, the law reaches the case." ${ }^{94}$

Similarly, in Trebilcock $v$. Wilson, ${ }^{90}$ in his dissenting opinion, Justice Bradley declared:

"Only in those cases in which gold and silver are stipulnted for as bullion, can they be demanded in specie like any other chattel. Contracts for specie made since the legal tender acts went into operation, when gold became a commodity subject to market prices, may be regarded as contracts for bullion. But all contracts for money made before the acts were passed must, in my judgment, be regarded as on the same platform. No difficulty can arise in this view of the case in sustaining all proper transactions for the purchase and sale of gold coin." 00

The definite advantage of the bullion obligation over a gold coin obligation arises at a time when gold coin becomes unavailable, or where by legislation or court decision contracts for gold coin are declared to be dischargeable in their face amount of legal tender.

92. Such a bill has been proposed by Representative Campbell. H. R. 14604, Feb. 8, 1933. A discussion of the constitutionality of such a law is beyond the scope of this article. The difficulty of determining its constitutionality lies not so much in the restraints imposed by the Constitution, which would not appear to be applicable, as in finding the power in Congress to enact such a law. Such a statute might be deemed incidental to the power to coin money and regulato the value thereof (see note 13, supra), as this power was broadly construed by the Supreme Court in the Legal Tender Cases, supra note 10, and particularly in the opinion of Justice Bradley in that case. It has already been held that the states have no power to pass such legislation. Garis, supra noto 4; Dennis v. Moses, 18 Wash. 537, 52 Pac. 333 (1898).

93. Note 10, supra.

94. Id. at 566.

'95. Note 21, supra.

96. Id. at 699. (Italics supplied). 
Even the Feist case did not purport to rule that contracts to deliver gold bullion would be affected by the suspension of the gold standard. However, the use of the bullion clause under existing regulations restraining dealings in bullion is open to grave doubt. Moreover, from the standpoint of use in bonds, the clause involves the fatal disadvantage of non-negotiability and uncertainty of the amount to be repaid. ${ }^{97}$ While in a few instances this may not be a controlling consideration, in most cases it renders the clause quite unworkable.

\section{IV}

\section{Commodity Clauses and Stabilized Units of Value}

While there is at the present time a very strong movement among economists and legislators to define and to put into force the necessary measures to stabilize the purchasing value of currencies either independent of gold or tied to gold, ${ }^{88}$ this stability remains still to be achieved. Pending such stabilization any provisional measures available to private parties contracting with reference to future payments can be considered as directed toward the protection of their obligations against fluctuations in the value of the currency measuring their debts.

As a matter of historical interest, debt obligations have been made solvable in a great variety of ways. Rents and taxes in economically backward countries were quite commonly payable in

97. Under $\S 1(2)$ of the N. I. L., an instrument to be negotiable must conform with the requirement that it "contain an unconditional promise or order to pay a sum certain in money." Under this provision, if the paper is so drawn as to be payable in commodities or labor, or in any other medium than money, it is not negotiable. A commodity note is clearly non-negotiable: Broolss v. Greil Bros., 192 Ala. 235, 68 So. 874 (1915); President and Directors of Manhattan Co. v. ITorgan, 242 N. Y. 38, 150 N. E. 594 (1926), holding an interim certificate nonnegotiable. In New York, under the Hofstadter Act, N. Y. PErsonsr PropenTY LAW (1926) art. VIII, $\S \S 260-2$, security receipts, equipment trust certificates and corporate bonds which by their terms entitle the bearer to the benefits thereof are given certain aspects of negotiability. The Hofstadter Act does not by its terms exclude from its benefits any bond for the payment of an uncertain amount or calling for delivery of gold bullion. It is not clear whether the strict requirements of the N. I. I. with respect to the payment clause hare any bearing with reference to bonds in New York.

98. A number of measures designed to have this effect are now being discussed in Congress. One of the most recent proposals is the Connally Bill (73d Cong., 1st Sess., S. B. 1111, introduced MFarch 13, 1933), which provides for the creation of a new currency of flexible gold value, the mint rate of the currency varying daily in accordance with wholesale price fluctuations. See Fismen, Stabilizing the Doluar (1920). 
kind in the produce of the debtor.99 $A$ variation on this practice of using commodities as a measure of value was employed in certain leases which provided for the payment of a certain quantity of a given commodity which was not produced by the lessee, but which was used solely as a measure of value. In such cases payment might actually have been made in money equal in amount to the cost of the stipulated quantity of the commodity specified in the contract.100 In Germany, following the war, loans were floated in terms of grain and other commodities and a law passed in June, 1923, sanctioned the issue of such obligations.101 One of the first obligations of this character was the Mecklenburg Schwerinsche Roggenvert Anleine, a rye loan. ${ }^{102}$ The payments under this loan were to be made in money equivalent in amount to the sum necessary to purchase a definite quantity of rye on the Berlin Produce Exchange.

The price of a given commodity may fluctuate more than gold, and if the commodity is bulky or perishable its value may vary greatly from one place to another, thus adding to the instability of the value of the obligation. A more stable unit of value may be devised by using as the measure of the obligation a number of commodities or an index number calculated by averaging the relative values in terms of currency of a number of commodities. Contracts calling for payments in money, the amount of which is to be calculated upon the currency value of several commodities, have not been unknown in the past. The tabular standard in use in the Massachusetts Bay Colony in 1780 was enacted by law for rating bills of public credit. Notes were issued specifying: "Both Principal and Interest to bo paid in the then current Money of said State, in a greater or less Sum, according as Five Bushels of Corn, Sixty-Eight Pounds and four sevenths Parts of a Pound of Beef, Ten Pounds of Sheep Wool, and Sixteen Pounds of Sole Leather shall then cost, more or less than One Hundred and Thirty Pounds current Money, at the then current prices of the said articles." 103 There is even a record of

99. English Tithes were, for example, measured in agricultural produce. FisHer, THE MONEY ILUUSION (1928) 116 et seq.

100. Fisher, loc. cit. supra note 99, describes such a lease where the d'ent was payable in "First quality of Old Russian Sables Iron."

101. Law of June 23, 1923. REIcHSGESETZBLATT (1923) 407.

102. Madden and Nadler, supra note 4 , at 23 , in describing this loun, remark: "Obligations stated in commodities have not proved very satisfactory, and as a result a large part of them have either been repaid or havo been converted into gold obligations. The reason for the werkness of this class of obligation is due to the fact that an individual commodity is subject to greator fluctuation than the price of gold."

103. Fischer, The Tabular Standard in Massachusetts History (1013) 27 QUART. J. OF ECON. 417, 437. These notes, known as "depreciation notes," woro issued to pay soldiers and were in use for several years. 
a valuation of such a note having been made by a court. 10 in Australia, mortgages have recently been drafted providing for an adjustable currency debt, the exact amount due being determined by using the weighted average index for "food, groceries and rent for all houses for the six capital cities" published in the Quarterly Summary of Australian Statistics. ${ }^{105}$

In one case at least a public loan was issued in the United States wherein both principal and interest were to be paid in "stabilized" dollars. This was the Rand Kardex Company Seven Per Cent. Thirty Year Stabilized Debenture Bonds obligation. ${ }^{100}$ The obligation of the Company was to repay upon a certain date "such sum of money as shall possess the present purchasing power of One Thousand Dollars $(\$ 1,000)$ with interest thereon at the rate of seven per cent. per annum, payable quarterly on January first, April first, July first and October first, in such sums as shall, at the respective times of payment, equal in purchasing power one and seventy-five one hundredths per cent. (1.75\%) of said purchasing power of One Thousand Dollars $(\$ 1,000)$, all to be based upon an index number of the prices of commodities defined and fixed in accordance with the amplified statement below." 107 The index employed was the United States Bureau of Labor Statistics index number of wholesale prices. A system is worked out whereby the actual amount payable in dollars is adjusted to the movement of the wholesale index. The stabilization employed in this loan was designed to operate both in raising and lowering the amount to be paid to the bondholder.

The defects of a form of payment clause such as this are twofold: first, the very doubtful negotiability of the bonds in view of the uncertainty of the amount to be paid; ${ }^{108}$ and second, the mechanical difficulties that may arise in connection with the workings of the index employed for measuring the amount to be paid in money. Corporate bookkeeping under an index clause system for long term loans would be extremely difficult. The weighting of the index and the component elements of the index are subject to change and this change might

104. Four justices of the "Supreme Judicial Court" filed a certificate of the prices found for the four staples and concluded that each pound of face value was worth $91 / 5$ d. of silver. Miassachusetts Archives, 142, p. 310, cited in FISCHER, supra note 103 , at 445 .

105. Watts, Inflation Clauses in Mortgages and Lcascs (1931) 4 AusT. L. J. 315.

106. The agreement is dated July 1, 1925. The loan was called by the company a few years after it was issued.

107. Agreement between Rand Kardex Company, Inc. and Buffalo Trust Co., 1, p. 5.

108. Note 97 , supra. 
result in a radical departure from the bases of measuring the index of wholesale prices.109 Moreover, if the particular index stipulated in the bond should be abandoned altogether, an event over which neither the company, the trustee nor the bondholders could havo any control, a difficulty would immediately arise as to how the debt should be measured. It is provided in the Rand Kardex loan agreement that should the Bureau of Labor Statistics discontinue the computation of the index, "there should be substituted therefor by the Trustee, as specified more fully in said indenture, such other index number or method of ascertaining changes in the price level as resembles in the opinion of the Trustee most closely the index number and method of arriving thereat of such Bureau." This arrangement is not entirely satisfactory as it imposes somewhat too great a responsibility upon the trustee.

Furthermore, since the chief sanction for the index clause is that its use enables the parties to eliminate fluctuations in the value of money qua money and to deal in real purchase values, the component elements of the index must be constantly adjusted to represent at all times the actual values of surrounding life. How periodic adjustments in the index could be effected without endangering the rights of a holder of an "index" obligation is problematical. For the purpose of international loans, some authority other than a national governmental bureau's index figures might be necessary. It has recently been suggested by Sir Arthur Salter ${ }^{110}$ that the League of Nations or the Bank for International Settlements publish poriodically an authoritative index, or several indices of world prices, so that those desiring to do so could use these indices for long-term contracts. While Sir Arthur Salter's idea meets the objection directed against any one national index because of its control by one government, his proposed index would necessarily have many drawbacks. Before an international index could become acceptable to prospective borrowers and lenders all over the world, there would have to be some assurance that it would be permanent and that improper alteration of the basis of the index figures would not be made by interested nations or private interests representing commodities. ${ }^{111}$ It is equally evident that it is impossible for anyone to

109. There is also the question of whether the wholesale commodity index as the standard of value is an appropriate measure of the debt inasmuch as most bondholders would be more interested in retail prices which do not fluctuato in direct proportion to the wholesale index and have a tendency to lag behind the wholesale index.

110. Sir Arthur Salter, $A$ Year and a Half of Crisis (1933) 22 Yale Rev. $217,230$.

111. The determination of an international index which could becomo immensely important to debtors and creditors alike could scarcely bo conflded to any body subject to interference by political interests of different countries. 
fix at this time a national or an international index for all time, or even for a decade, which after the lapse of several years will be properly weighted. It would seem that elaborate machinery for maintaining a reliable international index would only be called into operation by the complete breakdown of the gold standard in all countries and the universal loss among business people of hope in the restoration of the currencies of the world to a workable gold standard. But these objections having been raised, there is much to be said in favor of Sir Arthur Salter's idea of an international index. It would give a uniform basis for values, regardless of the gold reserves in the various countries or the stability of their currencies, and yet in so doing it would, without disturbing debt values, allow for variations in currency exchange values resulting from local conditions.

The chief deterrent to the floatation of loans containing an "index" clause is the practical consideration of the unfamiliarity of the investing public with the workings of such indices and its apparent apathy to the need for any improvement upon the gold coin clause as a measure of value. So long as the investing public is content to invest in bonds payable in currency or in gold coin, so long as borrowers are willing to obligate themselves to pay in gold coin in the future, regardless of its value, no immediate need is likely to arise for an "index" clause. But if a demand for an index clause should ever materialize, a clause could no doubt be drafted to meet many of the objections noted, and questions of negotiability, listing of index clause securities on stock exchanges and valuations of the debt for various purposes, while presenting formidable and novel problems, could be solved by new legislation if not solvable by the adoption of new practices in financial circles.

The inevitable conclusion concerning the utilization of any index clause is that only the gravest emergency would make desirable or possible its adoption as a measure of debts and that if the commodity index is indeed a sound measure of value it would be well to adopt it as the basis of currency ${ }^{112}$ rather than of individual debts. Perhaps this emergency is now at hand. But so long as there is a definite prospect that the world's currencies will be restored to the gold standard, the adoption of such indices in loan contracts would appear to be undesirable and impractical.

112. Note 98, supra. 